\title{
RADIOCARBON AND THE OLD WORLD ARCHAEOLOGY: SHAPING A CHRONOLOGICAL FRAMEWORK
}

\author{
Yaroslav V Kuzmin \\ Institute of Geology and Mineralogy, Siberian Branch of the Russian Academy of Sciences, Koptyug Ave. 3, Novosibirsk \\ 630090, Russia. Email: kuzmin@ fulbrightmail.org.
}

\begin{abstract}
The inception of the radiocarbon dating method in 1949 was immediately supported by many archaeologists. In the following 2 decades, many important archaeological sites in the Old World were dated, marking the beginning of building a reliable chronological framework for prehistoric and early historic cultural complexes worldwide. The author presents an observation of some of the most important results in establishing a chronology for Old World archaeology, based on ${ }^{14} \mathrm{C}$ dating performed in the last $50 \mathrm{yr}$. An extensive bibliography should help scholars to get acquainted with early summaries on archaeological chronologies based on ${ }^{14} \mathrm{C}$ data and their evaluation, as well as with some recent examples of the application of ${ }^{14} \mathrm{C}$ dating in Old World archaeology.
\end{abstract}

"And the earth was without form, and void; and darkness was upon the face of the deep." (Genesis 1:2)

\section{INTRODUCTION}

The importance of radiocarbon $\left({ }^{14} \mathrm{C}\right)$ dating for archaeology is impossible to underestimate. For example, as Renfrew (1973:20) noted, "Dating is crucial to archaeology. Without a reliable chronology the past is chaotic: there is no way of relating or ordering people, events, and cultures into the coherent narrative which the prehistorian seeks to construct." With the discovery of the ${ }^{14} \mathrm{C}$ dating method in 1949, archaeologists obtained a powerful tool to shape the chronology of human prehistory and early history. One can say that without such a reliable and precise scientific dating technique archaeology has roamed in the darkness (indirectly) like the Earth on the first day of creation; see Epigraph.

Since the early to mid-1950s, soon after the inception of ${ }^{14} \mathrm{C}$ dating, laboratories devoted to age determination by this method began to be founded in North America, Europe, Australia, New Zealand, and Asia. The amount of ${ }^{14} \mathrm{C}$ dates increased dramatically since the late 1950s, and prehistoric chronologies worldwide started to take shape. In the 1980s and 1990s, there were more than 100 laboratories routinely conducting ${ }^{14} \mathrm{C}$ dating of various materials from archaeological, geologi$\mathrm{cal}$, and other contexts (Waterbolk 1999:17). Among the advantages of applying the ${ }^{14} \mathrm{C}$ dating method in archaeology include: a) the possibility of creating an absolute timescale; b) correlation of archaeological sequences for distant regions; and c) comparison of archaeological sequences with environmental records (Waterbolk 1983b). Today, it is almost impossible to imagine serious archaeological research without extensive use of ${ }^{14} \mathrm{C}$ dating. Several textbooks and book chapters have been written to introduce the ${ }^{14} \mathrm{C}$ dating method and its applications to archaeologists and anthropologists (e.g. Taylor 1987, 1997; Aitken 1990; Dincauze 2000:107-17; Renfrew and Bahn 2004:1419; see also Waterbolk 1971).

The ${ }^{14} \mathrm{C}$ dating method underwent several major developments and improvements since its emergence. In the keynote address, "Radiocarbon: The Continuing Revolution," to the 19th International Radiocarbon Conference on 3 April 2006 in Oxford (UK), Prof Colin A Renfrew mentioned several "revolutions" in dating of prehistory. Among them, there are 1) the invention of ${ }^{14} \mathrm{C}$ dating method in the late $1940 \mathrm{~s} ; 2$ ) the calibration of the ${ }^{14} \mathrm{C}$ timescale in the late 1960s/early $1970 \mathrm{~s} ; 3$ ) the introduction of wiggle-matching of tree-ring sections and the accelerator mass spectrometry (AMS)

C 2009 by the Arizona Board of Regents on behalf of the University of Arizona Celebrating 50 Years of Radiocarbon

RADIOCARBON, Vol 51, Nr 1, 2009, p 149-172 
detection method in the late 1970s; and 4) the development of advanced approaches in data processing, such as Bayesian statistics in the 1980s and 1990s (see also Waterbolk 1999; Taylor 2000:95; Renfrew 2007). The ${ }^{14} \mathrm{C}$ method and its archaeological applications continue to evolve, and new discoveries and achievements are underway. International "Radiocarbon and Archaeology" conferences are held regularly; the first two were carried out in Groningen (the Netherlands) in 1981 and 1987; the third meeting in Lyon (France), 1998; the fourth symposium in Oxford (UK), 2002; and the fifth one in Zürich (Switzerland), in May 2008 (the proceedings of which will be published as a special issue of Radiocarbon). The transactions of these meetings contain a plethora of information about the application of the ${ }^{14} \mathrm{C}$ dating method to archaeology worldwide.

The journal Radiocarbon since its launch in 1959 serves as crucial medium between ${ }^{14} \mathrm{C}$ dating laboratories and the scholarly community. Now, when we celebrate 50 years of the journal's existence, it seems logical to remind the readers of the impact of ${ }^{14} \mathrm{C}$ analysis on the construction of cultural chronologies by looking back to see the "historic" development of applying ${ }^{14} \mathrm{C}$ dating to archaeology. Bar-Yosef (2000) addressed 2 important issues in ${ }^{14} \mathrm{C}$ dating of Old World archaeology: the Middle to Upper Paleolithic transition and the emergence of agriculture. He concluded that, "In sum, the last decade of ${ }^{14} \mathrm{C}$ dating has already made a significant impact on archaeological and historical interpretations. In an atmosphere of improved cooperation between scientists and archaeologists, new avenues of research can bring us revolutionary answers to old questions" (Bar-Yosef 2000:34). Expanding the geographic boundaries to Europe, mainland Asia, and Africa, I present here an observation of some of the most important achievements in ${ }^{14} \mathrm{C}$ dating of Old World prehistoric cultural complexes, especially in the early years (prior to 1970), with more details for Asia and Africa and a particular focus on studies published in Radiocarbon. This paper is not intended to provide a critical analysis of major research problems in the application of the ${ }^{14} \mathrm{C}$ method to archaeology due to the limitation of space and scope. Comprehensive catalogs of ${ }^{14} \mathrm{C}$ dates and descriptions of the Holocene cultural complexes from the Old World may be found in a compendium edited by Ehrich (1992). General chronological frameworks can be found in Fagan (1996:805-12).

When I refer in this paper to ${ }^{14} \mathrm{C}$ date lists only, the references to the volume and pages of Radiocarbon where it is published are given in square brackets; full texts are available free from the journal's Web site (www.radiocarbon.org). Calibration of ${ }^{14} \mathrm{C}$ dates is performed with the help of CALIB 5.0.1 software (see Reimer 2004; http://calib.qub.ac.uk/calib/). Another widely distributed calibration program is CALPAL (e.g. Weninger and Jöris 2004). Calibrated ages are in cal BC/AD years with $\pm 1 \sigma$, and all possible calendar intervals are combined and rounded to the next $10 \mathrm{yr}$. The spelling of archaeological sites and complexes generally follows Bahn (2001), and geographic and state names are mainly from Merriam-Webster's Geographic Dictionary (3rd edition, 1997).

\section{THE EARLY USE OF RADIOCARBON DATING METHOD IN OLD WORLD ARCHAEOLOGY}

As many know, the radiocarbon dating method was invented in 1945-1948 by Willard F Libby and his colleagues Ernest C Anderson and James R Arnold; the first paper explicitly describing the method (Libby et al. 1949) was released on 4 March 1949. In a second paper published in December 1949, the focus was given to the "known age" samples of archaeological origin (Arnold and Libby 1949). Since the very beginning, this research was supported by archaeologists, primarily by the Viking Fund (now Wenner-Gren Foundation for Anthropological Research), which provided funding in 1947 for the pilot project (e.g. Marlowe 1980; Taylor 1987:154). In fact, the first ${ }^{14} \mathrm{C}$ measurement (by University of Chicago, lab code C-1) was done on wood from the tomb of the Egyptian pharaoh Zoser (Libby 1965:77; see also Libby 1980). In the first list of $148{ }^{14} \mathrm{C}$ dates from Chicago published in 1950, "archaeological" values constitute $62 \%$ of the total amount; the ones from the Old 
World are about 24\% (see Taylor 2000:94). W F Libby's collaboration with archaeologists continued after he moved to the University of California at Los Angeles (Berger 1992; see also Burleigh 1981).

Announcements about the new dating method appeared in archaeological periodicals soon after publications by Libby and coauthors (e.g. Merill 1948; Crawford 1949; Griffin 1949). It was stressed that, "Dating sites and objects is the prime objective of archaeology, and absolute dating the ultimate objective. For until an orderly sequence of events has been established there can be no history, and without an absolute chronology the relations between cultures and civilizations must remain obscure and uncertain" (Crawford 1949:114). From this time on, close collaboration between archaeologists and ${ }^{14} \mathrm{C}$ specialists was established and quickly grew worldwide. The number of ${ }^{14} \mathrm{C}$ dates accumulated through the first decade of systematic application of the ${ }^{14} \mathrm{C}$ dating method (1950-1960) may be estimated as about 2000 values. Jelinek (1962) was able to compile a comprehensive list of ${ }^{14} \mathrm{C}$ dates from archaeological sites worldwide produced prior to 1961 ; it includes about 1140 values from the Old World (750 for Europe; 230 for Asia; and 165 for Africa).

Initial results of ${ }^{14} \mathrm{C}$ dating conducted at the University of Chicago laboratory in $1948-1950$ were interpreted in the early 1950s (Jennings 1951). Scholars who studied Old World archaeology and submitted samples generally accepted the results as reliable (Jennings 1951:50-3). However, some archaeologists, like V M Milojčić in Germany (see Renfrew 1973:30-57; Waterbolk 1983a:21-5) and S Yamanouchi in Japan (see Imamura 1996:46-50; Habu 2004:37), rejected the first results of ${ }^{14} \mathrm{C}$ dating of the prehistoric complexes in central and western Europe and east Asia. The reason was that ${ }^{14} \mathrm{C}$ dates did not fit with chronological schemes, which were based on the paradigm of diffusion of cultural innovations from a single center to the periphery. Subsequent research has shown that ${ }^{14} \mathrm{C}$ data from these regions were for the most part correct (e.g. Watanabe 1966; Renfrew 1973).

\section{MAJOR RESULTS IN ${ }^{14} \mathrm{C}$ DATING THE PREHISTORY AND ITS IMPACT ON OLD WORLD ARCHAEOLOGY}

\section{Europe}

European records of ${ }^{14} \mathrm{C}$ dates from archaeological contexts are the most numerous in the Old World. The age of European prehistoric monuments was intensively studied since the early 1950s. In the late 1940s and early 1950s, Libby (1965) dated several key sites in western Europe, such as Lascaux Cave, Stonehenge, and Starr Carr. For eastern Europe, ${ }^{14} \mathrm{C}$ dates from archaeological contexts became available in the 1960s (e.g. [Radiocarbon 6:308-17; Radiocarbon 7:223-8; Radiocarbon 8:27-45]). The announcement of some of the initial ${ }^{14} \mathrm{C}$ values for European prehistoric sites was made by McBurney (1952).

One of the first ${ }^{14} \mathrm{C}$ dates for European archaeological objects was the value of $3670 \pm 150 \mathrm{BP}$ (BM46) from Stonehenge (UK) [Radiocarbon 2:27], or 2290-1830 cal BC. Renfrew (1973:102) estimated the age of Stonehenge as before 2000-1800 BC. Among Paleolithic sites, some of the first ${ }^{14} \mathrm{C}$ dates were obtained from Lascaux Cave in France: 15,516 \pm 900 BP (C-406) (Libby 1965:85); and from Altamira Cave in Spain: 13,900 \pm 700 BP (M-828) and 15,500 \pm 700 BP (M-829) [Radiocarbon 2:46]. For one of the largest Neolithic flint mines in Europe, Grimes Graves (UK), $2{ }^{14} \mathrm{C}$ values of $4050 \pm 150 \mathrm{BP}(\mathrm{BM}-88)$ and $4270 \pm 150 \mathrm{BP}(\mathrm{BM}-87)$ were gained [Radiocarbon 3:41]; the calendar ages of which are 2870-2460 and 3090-2630 cal BC, respectively. These dates were considered as possibly too young ([Radiocarbon 3:41] but see Ambers 1998:599). Further ${ }^{14} \mathrm{C}$ dating of the Grimes Graves is summarized by Ambers (1998). As for early historic sites and finds, the age of the Oseberg clinker-built ship (Norway), used for the burial of a Viking chief, was determined as $1190 \pm 60 \mathrm{BP}$ (T-37) [Radiocarbon 1:79], which corresponds to a calendar age of cal AD 730-940, 
and it is in accord with the historical date of ship of around AD 815-820 and dendrochronological date of the burial as AD 834 (e.g. Fitzhugh and Ward 2000:88-9). These examples prove that the ${ }^{14} \mathrm{C}$ dating method, since its inception, has been an important research tool in European prehistory.

The accumulation of ${ }^{14} \mathrm{C}$ information in the 1960s and 1970s enabled a better understanding of the major chronological patterns in European prehistory. Watts (1960) presented initial results of ${ }^{14} \mathrm{C}$ dating the Irish archaeological complexes in sketchy fashion. The first observations of ${ }^{14} \mathrm{C}$ dating the European Paleolithic complexes were given by Movius (1960) and Smith (1965). Bandi (1965) produced a brief summary of the Mesolithic ${ }^{14} \mathrm{C}$ chronology in central Europe. One of the first papers on the ${ }^{14} \mathrm{C}$ chronology of domestic animals in Europe and the Near East was given by Protsch and Berger (1973). Switsur and Jacobi (1979) presented the chronology of the Mesolithic complexes in England and Wales. Tauber (1990) gave a general chronological framework of Danish prehistory.

The study of the emergence of the Neolithic (i.e. complexes based on productive economy) in Europe received a new impulse with the introduction of ${ }^{14} \mathrm{C}$ dating. Clark (1965) created the first model of agricultural spread from the Levant to Europe using ${ }^{14} \mathrm{C}$ results of the earliest Neolithic sites in both regions; he also constructed the first general outline of the European Neolithic chronology and offered a much older age of the earliest farming communities in Europe compared with estimates made on purely archaeological and historical grounds. The chronology of the European Neolithic was discussed in more detail by Quitta (1967) and Waterbolk (1968).

One of the first broad interpretations of ${ }^{14} \mathrm{C}$ data in conjunction with archaeological knowledge was given by Renfrew (1973) (see also Renfrew 2007:43-52). He showed that the traditional diffusionist paradigm of V G Child's was first challenged by ${ }^{14} \mathrm{C}$ dates and collapsed afterwards. Later on, a new chronological framework based on calibrated ages was constructed for Europe and the Near East (Renfrew 1973). The importance of Renfrew's pioneering creative analysis of ${ }^{14} \mathrm{C}$ information for European prehistory can hardly be underestimated. As European and Mediterranean archaeological chronologies were continued to be refined, recent studies (e.g. Bruins and van der Plicht 1996; Bronk Ramsey et al. 2004) on the precise dating of the catastrophic eruption of Thera Volcano at Santorini (Aegean Islands, Greece) in the 2nd millennium BC, and its serious impact on humans, are especially noteworthy.

The ${ }^{14} \mathrm{C}$ dating method allows for establishing the direct age of cultural and religious relics via a scientific approach. The ages of several important European objects-for example, the Shroud of Turin (Damon et al. 1989); Etruscan Linen Book [Liber Linteus Zagrabiensis] (Srdoč et al. 1990); Crown of Charlemagne [Corona Ferrea of Monza] (e.g. Tuniz et al. 1998:234-5); Vinland Map parchment (Donahue et al. 2002); and icons of Kievan Rus (Kovalyukh et al. 2001)-were securely determined. Also, the direct dating of human-modified organic tools and other items allowed a chance to evaluate the reliability of the ${ }^{14} \mathrm{C}$ dating of associated material such as charcoal and non-modified animal bones (e.g. Smith and Bonsall 1990; Tolan-Smith and Bonsall 1999). One of the most evident cases of using ${ }^{14} \mathrm{C}$ dating in conjunction with other chronometric methods is the age determination of a timber circle at Holme-next-the-Sea (UK) as 2949 BC, with the precision of 1(!) calendar year (Bayliss et al. 1999).

An important aspect of ${ }^{14} \mathrm{C}$ studies in prehistory is the direct dating of humans and other objects. In Europe, significant progress in dating the remains of Late Pleistocene people was achieved in the last decade (e.g. Ovchinnikov et al. 2000; Pettitt and Bader 2000; Pettitt et al. 2000; Richards et al. 2001; Schmitz et al. 2002; Trinkaus et al. 2003; Conard et al. 2004; Kuzmin et al. 2004a; Schulting et al. 2005; Wild et al. 2005; Higham et al. 2006a,b; Soficaru et al. 2006; Street et al. 2006). It is clear now that only direct ${ }^{14} \mathrm{C}$ dates of human remains can serve as proof of the suggested age (e.g. 
Smith et al. 1999:12,284; Anikovich 2005:79; Keates et al. 2007). This conclusion became possible after revealing that several presumed Pleistocene human finds from central Europe turned out to be much younger (see e.g. Berger and Protsch 1989:64 versus Street et al. 2006). Another important issue is the sample pretreatment (e.g. Higham et al. 2006b; Brock et al. 2007); for example, the application of the ultrafiltration technique allowed an increase reliability of dating, and is especially important for "old" samples. Direct ${ }^{14} \mathrm{C}$ dating of rock art in European Paleolithic caves (e.g. Valladas et al. 1992, 2001) is now an important part of chronological studies (see review: Pettitt and Pike 2007). Recent cross-dating of charcoal from the floor of Megaloceros gallery in Chauvet Cave (France) gave a consistent date of $\sim 31,600 \mathrm{BP}$ (Cuzange et al. 2007). Pettitt (2008) challenged such an old age of the rock art (which has direct ${ }^{14} \mathrm{C}$ date of $\sim 31,350 \mathrm{BP}$ ) and suggested that it may be about 27,000 BP (see also discussion in Balter 2008). Only more ${ }^{14} \mathrm{C}$ dates of the painting itself can solve this situation, although the sampling can severely damage art images (Balter 2008:905).

In this overview article, it is impossible to mention all the major case studies in the ${ }^{14} \mathrm{C}$ chronology of European prehistoric complexes. Therefore, a short synopsis of 2 aspects is given below: 1) the Middle to Upper Paleolithic transition and the appearance of modern humans; and 2) the spread of agriculture and pottery. A brief review of the Upper Paleolithic chronology in Europe was published by Djindjan (1999). Aldhouse-Green (1998) and Higham et al. (2006b) presented recent results of ${ }^{14} \mathrm{C}$ dating of the British Upper Paleolithic. Summaries on the ${ }^{14} \mathrm{C}$ chronology for Middle and Upper Paleolithic complexes in western and central Europe have been recently released by Conard and Bolus (2003), Straus and González Morales (2003), Verpoorte (2005), Gravina et al. (2005), Mellars (2006a,b), Zilhão (2007), and Finlayson et al. (2008). Data on the early Upper Paleolithic chronologies in central and eastern Europe are presented in a volume edited by Brantingham et al. (2004). Svezhentsev and Popov (1993) and Abramova et al. (2001) compiled chronologies of the Middle and Upper Paleolithic of the Russian Plain and adjacent Urals, with some additional information given recently by Pavlov et al. (2004), Anikovich (2005), and Sinitsyn and Hoffecker (2006).

Significant progress in the chronology of Neolithic complexes (i.e. with both pottery and agriculture) in Europe has been achieved since the pioneering research done by Clark (1965). Stäuble (1995) and Gronenborn (1999) reviewed the earliest ${ }^{14} \mathrm{C}$ dates from the Neolithic of central Europe. Forenbaher and Miracle (2005) collected information on the emergence of farming in the coastal southern Balkans, and Zilhão (2001) and Zapata et al. (2004) provided evidence from the western Mediterranean. Fischer and Kristiansen (2002) compiled papers about the beginning of the Neolithic in southern Scandinavia and northern Germany. Fairweather and Ralston (1993), Schulting (2000), and Brown (2007) put together ${ }^{14} \mathrm{C}$ evidence for the earliest cultivation in the British Isles. Berstan et al. (2008) ${ }^{14} \mathrm{C}$ dated lipids in pottery found at the Early Neolithic site of Sweet Track (UK) and compared results with dendrochronological data (the agreement is excellent). Krajcar Bronić et al. (2004) presented the chronology of the earliest Neolithic in the Balkans, while Bonsall et al. (2004) and Borić and Miracle (2004) published the results of their study in the Iron Gates [Djerdap Gorge] region of the Danube Basin. Potekhina and Telegin (1995), Timofeev and Zaitseva (1999), and Dolukhanov et al. (2005) collected ${ }^{14} \mathrm{C}$ dates from the earliest Neolithic sites in eastern Europe.

The accumulation of a large amount of ${ }^{14} \mathrm{C}$ dates made it possible to conduct a numerical spatiotemporal analysis of the data sets. In the last $10-15 \mathrm{yr}$, frequencies of ${ }^{14} \mathrm{C}$ dates from European prehistoric sites are used as proxy records of human occupation and its correlation with climatic changes in the second part of Late Pleistocene (e.g. Vermeersch 2005). Several processes, such as the recolonization of Europe after the Last Glacial Maximum (LGM) (e.g. Housley et al. 1997; Blackwell and Buck 2003; Gamble et al. 2005; Shennan and Edinborough 2007); the emergence of Upper Paleolithic and modern humans and its relationship with climate (e.g. Zilhão and d'Errico 1999; Dolukh- 
anov et al. 2002; d'Errico and Goñi 2003; van Andel and Davies 2003; Bocquet-Appel et al. 2005; Ugan and Byers 2007); and the spread of the Neolithic (e.g. Pinhasi et al. 2000; Gkiasta et al. 2003; Davison et al. 2007), were investigated using ${ }^{14} \mathrm{C}$ data sets. The chronology of the appearance and spread of metalworking in central and eastern Europe, the Near East, and the Urals was established based on a ${ }^{14} \mathrm{C}$ database of archaeological complexes with the earliest evidence of metallurgy (Chernykh et al. 2000; Chernykh 2008).

In the modeling of the Neolithization process in Eurasia, the definition of principles for site selection should be rigorous. For example, Gkiasta et al. (2003) and Russell and Steel (2004) selected sites with evidence of domesticates for visualization of the spread of Neolithic. Davison et al. (2007) and Dolukhanov et al. (2005), however, combined 2 criteria of the Neolithization-agriculture and pottery-and included many sites from the central and northern parts of eastern Europe, which have pottery but lack domesticated animals and plants. As a result, their modeling seems to have little merit, because in the northern region of eastern Europe plant cultivation did not occur until the Bronze Age ( 4500-4000 BP) (see Kuzmin and Vetrov 2007:16-7), while the simulation shows the presence of the "agricultural" Neolithic at some sites at 7400 BP (Davison et al. 2007:148). The socalled "boreal Neolithic" without agriculture (Davison et al. 2007:140) is very different from the typical (i.e. agricultural) Neolithic of central Europe. The attempt to derive the European "non-agricultural" Neolithic with pottery from sources in the eastern part of Eurasia (the Urals and ultimately presumably East Asia) (Davison et al. 2007:153) where pottery is dated to the Late Glacial time (e.g. Kuzmin 2006a), is to some extent the continuation of the diffusionist approach, which failed to explain the development of European prehistoric cultures (see above). Thus, great caution should be taken for determining causes and consequences in the modeling of prehistoric phenomena based on ${ }^{14} \mathrm{C}$ data sets.

The LGM “depopulation” of Europe scenario (e.g. Hoffecker 2002:195-215; Banks et al. 2008), after dating of the Upper Paleolithic sites in central and eastern regions of the continent, should be rejected. It was shown that there are dozens of sites north and east of the Alps that are dated precisely to about 20,000-18,000 BP (e.g. Verpoorte 2004; Svoboda and Novák 2004; Bocquet-Appel et al. 2005; Street et al. 2006). Therefore, ${ }^{14} \mathrm{C}$ dating gives the opportunity to revise models of human occupations and migrations.

\section{Asia}

Because the Asian continent is so large, for the purpose of this observation it is subdivided into several geographic and cultural regions: Near East (includes the Levant, which comprises modern Israel, Palestine, Jordan, Lebanon, and Syria, along with neighboring parts of Turkey, Iraq, and Iran); Central Asia (modern states of the former USSR, including Uzbekistan, Turkmenistan, Tajikistan, Kyrgyzstan, and Kazakhstan); East Asia (Japan, China, Korea, and Mongolia); Siberia and the Russian Far East; Southeast Asia (Burma [Myanmar], Thailand, Laos, Cambodia, Vietnam, and Malaysia); and South Asia, or the Indian subcontinent (mainly modern India and Pakistan).

The Near East is the best-studied part of Asia in terms of prehistoric ${ }^{14} \mathrm{C}$ chronology. Initial research was performed at the advent of the ${ }^{14} \mathrm{C}$ dating method (Libby 1965; Johnson 1965:158-9; see also Jennings 1951:52-3; McBurney 1952). The Near East soon became a kind of "polygon" for the study of several important topics directly related to chronology, such as the emergence and spread of modern humans, the beginning of the Upper Paleolithic, and the origin of food production. Numerous key sites were ${ }^{14} \mathrm{C}$ dated in the 1950 s and 1960s; among them are Jarmo, Tell Hassuna, Matarrah, Mersin, Byblos, and Shanidar Cave [Radiocarbon 2:182-3]; Jericho, Nimrud [Kalhu], and Nippur [Radiocarbon 5:83-5]; Tabun and Shanidar caves, and Ksar Akil [Radiocarbon 5:172- 
4]; Nippur and Çatal Höyük [Radiocarbon 7:188-92]; and Çayönü [Radiocarbon 9:127-8]. One of the first results in interpreting ${ }^{14} \mathrm{C}$ records from the Levant was an analysis of Mesopotamian historic chronology versus ${ }^{14} \mathrm{C}$-derived ages (Mellaart 1979); it led J Mellaart to conclude that the ${ }^{14} \mathrm{C}$ dates after calibration fit well with the "high historic chronology."

The impact of ${ }^{14} \mathrm{C}$ dating on Near Eastern archaeology was briefly summarized by Henry (1992), who emphasized that "Of the many technological advances in modern archaeology, ${ }^{14} \mathrm{C}$ dating has had perhaps the greatest influence on shaping theoretical developments within Near Eastern prehistory." (Henry 1992:324). Updated summaries on the chronology of the Paleolithic, Neolithic, Chalcolithic, and the Bronze and Iron ages complexes from the Levant may be found in a volume edited by Bar-Yosef and Kra (1994), with a summary given by Waterbolk (1994), and in a special issue of Radiocarbon edited by Bruins et al. (2001). Particularly impressive is the research conducted by Aurenche et al. (2001), in which $731{ }^{14} \mathrm{C}$ reliable values were selected from an original set of about 1300 dates, in order to understand the time for the beginning of agriculture and animal breeding, the emergence of pottery, and the rise of urbanism in the Near East.

To illustrate the impact of ${ }^{14} \mathrm{C}$ dating on the archaeology of the Near East, some examples are necessary. Series of ${ }^{14} \mathrm{C}$ dates were generated from Upper Paleolithic layers of the Kebara Cave to secure the age of Ahmarian and Aurignacian complexes (Bar-Yosef et al. 1996). The AMS ${ }^{14} \mathrm{C}$ dating of cereal grains from the Middle Bronze Age layer at Jericho raised the issue of dating of the biblical Exodus event and its possible correspondence to the catastrophic explosion of the Thera Volcano in the Mediterranean Sea (Bruins and van der Plicht 1996). The long-standing discussion about the precise time of the emergence of agriculture was solved with the help of direct AMS ${ }^{14} \mathrm{C}$ dating of cultigen seeds at the Abu Hureyra site in the Euphrates River valley, with earliest values of about 11,150 10,600 BP (Hillman et al. 2001). A series of $60{ }^{14} \mathrm{C}$ dates from Öküzini Cave in Anatolia helped to establish the chronology of the Epi-Paleolithic complexes (Otte et al. 2003). Direct AMS ${ }^{14} \mathrm{C}$ dating of fig fruits in the Jordan Valley allows securing the beginning of its domestication at $9900 \mathrm{BP}$ (Kislev et al. 2006). An extensive program of ${ }^{14} \mathrm{C}$ dating of the key Iron Age sites in the Levant was done recently in order to check the reliability of biblical sources about the early history of the region (Levy and Higham 2005; Finkelstein and Piasetzky 2006; Sharon et al. 2007). This became possible only due to well-developed ${ }^{14} \mathrm{C}$ chronologies; for the refinement of the Iron Age of Levant chronology, roughly 400 new ${ }^{14} \mathrm{C}$ dates were employed. As a result, archaeologists were able to match historical events with particular sites and cultural layers (Levy and Higham 2005:3-14); nevertheless, the problem of dating accuracy, which is now $\sim 100 \mathrm{yr}$ only, still exists, but this is a minor issue compared to what was the case before the launch of this project.

The ${ }^{14} \mathrm{C}$ dating of written documents from the Holy Land is an exceptional case when early historical events described in the ancient manuscripts can be tested by independent dating. The first dating of linen used to wrap biblical texts (Book of Isaiah) from a cave near Ain Fashkha on the Dead Sea coast produced a ${ }^{14} \mathrm{C}$ value of $1917 \pm 200 \mathrm{BP}(\mathrm{C}-576)$ (Libby 1965:84). The calibrated date is 170 cal BC-cal AD 330, and it is broadly confirmed by the suggested age of 1st or 2 nd century BC. The second case is the ${ }^{14} \mathrm{C}$ dating of the famous Dead Sea Scrolls found in 1947 near the ancient settlement of Qumran [Khirbet Qumran], not far from Ain Fashkha. It is believed that the site was occupied mainly in the 1st century AD. Dating of scrolls produced ${ }^{14} \mathrm{C}$ ages of $\sim 2240-1980 \mathrm{BP}$ (390 cal BC-AD 60) (Bonani et al. 1992) and 2190-1760 BP (390 cal BC-AD 390) (Jull et al. 1995). All these results are in good agreement with paleographic and historical ages of the Dead Sea Scrolls.

In Central Asia, the degree of ${ }^{14} \mathrm{C}$ dating the prehistoric cultural complexes is still not satisfactory. The first dates were published in the 1960s and early 1970s [Radiocarbon 7:223-8; Radiocarbon 8: 316-8; Radiocarbon 12:141-4, 417-9; Radiocarbon 14:351-4]. However, only a small amount of 
${ }^{14} \mathrm{C}$ data is currently available for Pleistocene sites (e.g. Vishnyatsky 1999; Derevianko 2001; Ranov et al. 2002; Krivoshapkin et al. 2006), and not many dates were generated for Holocene complexes (e.g. Harris et al. 1996; Hall 1997; Levine and Kislenko 1997; Kuzmina 2008; Panyushkina et al. 2008). It is clear that more work needs to be done in order to establish a firm chronological framework for prehistoric and early historic periods in Central Asia.

In east Asia, Japan is the definite "champion" in terms of ${ }^{14} \mathrm{C}$ dating of archaeological sites. The application of ${ }^{14} \mathrm{C}$ dating truly revolutionized the prehistory of Japan. The first ${ }^{14} \mathrm{C}$ determinations were released in the 1960s: the oldest shell midden of Natsushima, $9450 \pm 400$ BP (M-769) and $9240 \pm 500$ BP (M-770) [Radiocarbon 2:45]; the earliest dugout canoe at Kamo site, $5290 \pm 140$ BP (N-38), and Paleolithic sites at Lake Nojiri, about 18,300-35,200 BP [Radiocarbon 8:327-35]; Paleolithic and Incipient Jomon layers at Fukui Cave (about 12,400-13,600 BP), and Araya site $(13,200 \pm 350 \mathrm{BP}$; GaK-948) [Radiocarbon 9:53-4] (see also [Radiocarbon 11:638]). These dates were soon interpreted and incorporated into the Japanese archaeological sequence (e.g. Ikawa 1964; Morlan 1967; Serizawa 1967, 1976; Hurley et al. 1976; Ikawa-Smith 1976). The complete ${ }^{14} \mathrm{C}$ date lists from Japanese Paleolithic sites and their interpretations, however, were published quite recently (Ono et al. 2002; Takamiya and Obata 2002). As for the Jomon of Japan, the first summary was released in the 1960s (Watanabe 1966; see also Aikens and Higuchi 1982:96, Figure 3.2), but the updated list of ${ }^{14} \mathrm{C}$ values was compiled much later (Keally and Muto 1982). The issue of the emergence of pottery in Japan has been extensively studied since the 1960s (e.g. Ikawa 1964; Morlan 1967), and recently it was summarized by Keally et al. (2004). A review of some aspects of ${ }^{14} \mathrm{C}$ dating in Japanese archaeology was recently given by Keally (2004). The Japanese ${ }^{14} \mathrm{C}$ archaeological chronology is quite a dynamic topic of research, and several key studies (e.g. Nakamura et al. 2001; Tsuji and Nakamura 2001; Yoneda et al. 2002; Mihara et al. 2004) show its potential.

In Korea, ${ }^{14} \mathrm{C}$ dating of archaeological sites was for a long time in the infancy stage (e.g. [Radiocarbon 12:351; Radiocarbon 14:277-8]), with only a handful of dates available before the 1980s (e.g. Nelson 1993:64-5, 114-5, 173). Comprehensive lists of ${ }^{14} \mathrm{C}$ dates from prehistoric sites were published in the 1990s and 2000s (Kim et al. 1993; Choe and Bale 2002:99-101; Bae and Kim 2003). Now, the main chronological patterns for Korean Upper Paleolithic, Neolithic, and the Bronze and Iron ages are established. Recently, several important prehistoric and early historic monuments were studied (e.g. Kim et al. 2004; Youn et al. 2004).

The first results of ${ }^{14} \mathrm{C}$ dating the prehistoric cultural complexes from the People's Republic of China (i.e. China) were released in the 1960s (e.g. [Radiocarbon 11:548]) and initially reviewed by Barnard (1972) and Chang (1973), with further summaries provided by Dai et al. (1990) and An (1991). The Holocene cultural chronologies began to take shape in the 1980s and 1990s, and a compendium of ${ }^{14} \mathrm{C}$ dates from archaeological sites in China was assembled and published by the Institute of Archaeology of the Chinese Academy of Social Sciences (1991). The main Neolithic, Bronze Age, and Iron Age complexes are now securely dated (e.g. Chang 1986; Yuan et al. 1995; Hall 1997; Underhill 1997; Crawford and Shen 1998; Wu and Zhao 2003; Shelach 2006). A large-scale project aimed to study the age of the earliest Chinese states (Xia, Shang, and Zhou), with the help of extensive ${ }^{14} \mathrm{C}$ dating of key sites was launched in the 1990s (e.g. Guo et al. 2000; Lee 2002), and its results confirmed and refined the historical chronology of early Chinese civilization. As for the Republic of China (i.e. Taiwan), the first ${ }^{14} \mathrm{C}$ dates from archaeological sites were published in the late 1960s and early 1970s [Radiocarbon 11:639-41; Radiocarbon 12:187-92; Radiocarbon 15:345-9].

The very early ${ }^{14} \mathrm{C}$ dates from Neolithic complexes (i.e. with pottery and without agriculture) in south China — older than $10,000 \mathrm{BP}$ - raised doubts about the validity for applying the ${ }^{14} \mathrm{C}$ method in areas with widespread limestone bedrock (An 1989). This problem was overcome by dating of terrestrial 
plant and animal remains (e.g. Wu and Zhao 2003:17). Methodological and archaeological problems associated with the chronology of the earliest pottery in China and neighboring regions of east Asia were examined by MacNeish (1999) and Kuzmin (2006a). Now, the Final Pleistocene age of the earliest Chinese pottery is securely established (e.g. Wu and Zhao 2003; Pearson 2005). As for the Late Pleistocene cultural complexes in China, the situation with ${ }^{14} \mathrm{C}$ dating in the 1970s and 1980s was not as good as with the Holocene cultures; only a few key sites were dated. The state of ${ }^{14} \mathrm{C}$ dating of the Upper Paleolithic sites gradually improved when several case studies were completed; for example, at Shuidonggou site in the Ordos region (e.g. Madsen et al. 2001) and at the Xiachuan site in the lower Yangtze River (Tang 2000). Recently, the corpus of ${ }^{14} \mathrm{C}$ dates from Paleolithic complexes in northern China ( 115 values) was assembled for numerical analysis (Barton et al. 2007).

In Mongolia, Paleolithic complexes were ${ }^{14} \mathrm{C}$ dated only in the 1990s (Derevianko 2001; Derevianko et al. 2003). As for the following prehistoric periods, their chronology is still very poorly studied; a few ${ }^{14} \mathrm{C}$ dates were obtained for Neolithic and Medieval complexes (Séfériadès 2004; Youn et al. 2007). More work is definitely needed for shaping the chronological framework of the ancient Mongolian cultural complexes.

The first series of ${ }^{14} \mathrm{C}$ dates from prehistoric sites in Siberia and the Russian Far East (Asiatic part of Russia) were published in the 1960s and early 1970s ([Radiocarbon 7:223-8; Radiocarbon 8: 315-9; Radiocarbon 10:435-6; Radiocarbon 12:145-52; Radiocarbon 14:357-62]; see also Chard 1962; Klein 1967). Initial summaries based on a limited amount of data became available in the 1970s (Dolukhanov and Timofeev 1972; Chard 1973; Michael 1984). Further studies brought significant progress in defining chronological framework for the Pleistocene sites (e.g. Mochanov and Fedoseeva 1985; Goebel and Aksenov 1995; Goebel and Slobodin 1999; Vasil'ev et al. 2002; Dolukhanov et al. 2002; Sulerzhitsky 2004; Kuzmin 2007) and Holocene cultural complexes (e.g. Ackerman 1982; Mochanov and Fedoseeva 1985; Zaitseva et al. 1993; Dumond and Bland 1995; Weber 1995; Sementsov et al. 1998; Kuzmin 2000, 2006b; Kuzmin and Orlova 2000; Kuzmin and Vetrov 2007; Görsdorf et al. 2001; Fitzhugh et al. 2002; Pitulko 2004; Timofeev et al. 2004; Chernykh 2008).

One of the most important discoveries in Siberian archaeology, made with the help of ${ }^{14} \mathrm{C}$ dating, is the Pleistocene age potteries in the Amur River basin, about 13,300-12,300 BP (e.g. Kuzmin 2006a; Nesterov et al. 2006), and in the middle course of the Vitim River, about 12,000-10,800 BP (Vetrov et al. 2006). This research allows the identification of at least 2 regions in northern Asia with very old ceramic vessels from hunter-fisher-gatherer complexes located far away from the traditional "cradles" of pottery-making, such as the Japanese Islands (e.g. Aikens and Higuchi 1982) and China (e.g. Chang 1986; Pearson 2005). Another significant application of ${ }^{14} \mathrm{C}$ dating is the very early beginning of the Upper Paleolithic with adornments, since at least 43,000 BP (e.g. Derevianko 2001). It is now clear that the Siberian Upper Paleolithic emerged almost simultaneously with Levantine complexes (e.g. Kuzmin 2007).

Several case studies devoted to establishing a firm prehistoric chronology were carried out in Siberia in the 1980s to 2000s. Among them, there are the time frames for the Upper Paleolithic sites of Kara-Bom (Goebel et al. 1993), Studenoe 2 (Goebel et al. 2000; Buvit et al. 2004; Kuzmin et al. 2004b), Yana RHS (e.g. Pitulko et al. 2007), Afontova Gora 2 (e.g. Damblon et al. 1996:203-4), Malta (e.g. Vasil'ev et al. 2002:526-7), Ushki (e.g. Goebel et al. 2003), Khotyk (Kuzmin et al. 2006), and Bol'shoj Naryn (Sato et al. 2008); age determination of the Mesolithic Zhokhov site in the High Arctic (Pitulko 2004); dating of the key Neolithic and Bronze Age complexes in the Lake Baikal region (Mamonova and Sulerzhitsky 1989; Weber et al. 2006); and wiggle-matching of the 
Early Iron Age (Scythian) sites in the Altai Mountains and Tuva (e.g. Alekseev et al. 2001; Dergachev et al. 2001; Kuzmin et al. 2004c; Zaitseva et al. 1998, 2007) and western Siberia (Borodovsky et al. 2003). The ${ }^{14} \mathrm{C}$ chronology of Siberian archaeological cultures develops in a very dynamic fashion.

The analysis of large ${ }^{14} \mathrm{C}$ date series and subsequent numerical modeling of the peopling and persistence of humans in Siberia is a comparatively new field for Siberian geoarchaeology. Several studies, based on the evaluation of the Paleolithic ${ }^{14} \mathrm{C}$ chronologies, were carried out (Kuzmin and Tankersley 1996; Goebel 1999; Dolukhanov et al. 2002; Kuzmin and Keates 2005; Graf 2005, 2009; Fiedel and Kuzmin 2007). There is still no consensus about the methodology of combining individual ${ }^{14} \mathrm{C}$ dates to reveal patterns of occupation (see discussion: Fiedel and Kuzmin 2007:750-1), and this problem needs to be solved quickly.

In east Asia and Siberia, there are still a few ${ }^{14} \mathrm{C}$ dates obtained directly on Late Pleistocene hominids, and this casts doubt on the estimated age of some human remains. A recent case of direct AMS ${ }^{14} \mathrm{C}$ dating of a femur from Ordos Plateau in northern China is a good illustration; the presumed Pleistocene human bone yielded a ${ }^{14} \mathrm{C}$ age of $\sim 200 \mathrm{BP}$ (Keates et al. 2007). There is another study by Shang et al. (2007) in which early modern human bone from one of the localities in Zhoukoudian area of north China returned a ${ }^{14} \mathrm{C}$ date of $\sim 34,400$ BP. Surprisingly enough, none of the Japanese presumably Pleistocene hominids (e.g. Ono et al. 1999:182) have been directly ${ }^{14} \mathrm{C}$ dated. In Siberia, only 3 Pleistocene human remains are directly dated: Malta [Mal'ta] site, 19,900 BP (Richards et al. 2001); and Okladnikov Cave, about 24,300-34,200 BP (Krause et al. 2007). However, the wide variation of ${ }^{14} \mathrm{C}$ values for the same specimen, like in the case of Okladnikov Cave where sub-adult humerus was dated in 3 different laboratories to $\sim 29,990 \mathrm{BP}, \sim 34,860 \mathrm{BP}$, and $\sim 37,800 \mathrm{BP}$ (Krause et al. 2007; Supplement, p. 2), makes these kinds of samples quite sensitive to contamination. The direct AMS ${ }^{14} \mathrm{C}$ dating of early modern humans is now widely employed in Europe (e.g. Trinkaus et al. 2003; Conard et al. 2004; Higham et al. 2006b:190-1), and it is therefore an urgent task to perform more ${ }^{14} \mathrm{C}$ dating of Pleistocene human remains from east Asia and Siberia.

For Southeast Asia, the first ${ }^{14} \mathrm{C}$ dates were published in the late 1950s, 1960s, and early 1970s (e.g. Harrisson 1958; Dunn 1966; Shutler 1967; Solheim 1968; Gorman 1969; Bayard 1972; see also [Radiocarbon 11:638]). One of the most important projects was the long-term excavation of the Niah Cave on Borneo Island (Malaysia) (Harrisson 1958; Barker et al. 2005) (see also [Radiocarbon $8: 479]$ ), where human occupation since at least $\sim 46,000 \mathrm{BP}$ is detected. ${ }^{14} \mathrm{C}$ dating program was performed at Spirit Cave in Thailand (Gorman 1969; Lampert et al. 2003; White 2004; see also [Radiocarbon 13:24]). A special study on the dating of the earliest rice cultivation in South and Southeast Asia was performed by Bellwood et al. (1992). It seems that Thailand and Malaysia are the 2 best-dated regions of Southeast Asia; for example, numerous ${ }^{14} \mathrm{C}$ dates were generated from sites in Sarawak, Borneo Island (Harrisson 1973, 1975; see also Shutler 1977), and some sites in peninsular Malaysia (e.g. Leong 2000). In Thailand, long-term archaeological projects brought a large amount of chronometric data, which allow for shaping the chronology of the prehistoric and early historic complexes (e.g. Higham 1987, 1989; Anderson 1997; White 1997; McGrath and Boyd 2001; Barram 2003; Higham and Higham 2009). Several ancient sites are ${ }^{14} \mathrm{C}$ dated in Burma (e.g. Hudson et al. 2002; Grave and Barbetti 2002), Laos (e.g. Sayavongkhamdy and Bellwood 2000), and Cambodia (e.g. Bishop et al. 2004; Zoppi et al. 2004; Penny et al. 2007; Uchida et al. 2008). More ${ }^{14} \mathrm{C}$ dates were generated for Vietnamese prehistoric complexes; this research began in the 1970s [Radiocarbon 20:387-96] and continues now (e.g. Nishimura and Nguyen 2002; Nguyen 2005; Yi et al. 2008). A review of some aspects of the ${ }^{14} \mathrm{C}$ prehistoric chronology for island Southeast Asia was given by Spriggs (2003). 
As for South Asia, the first ${ }^{14} \mathrm{C}$ dates were obtained in the 1960s for monuments of the Harappa civilization, Lothal (India) and Mohenjo-daro (Pakistan) [Radiocarbon 5:276-7; Radiocarbon 9:3334]. Summaries of archaeological chronologies were made in the 1970s and 1980s (e.g. Sankalia 1973; Tripathi 1990), while pioneering work was done in the 1960s by Agrawal (1965). Extensive studies of archaeological sites in India using ${ }^{14} \mathrm{C}$ dating allowed the creation of a solid chronological framework for Indian prehistory (Agrawal and Kharakwal 2002; Chakrabarti 2006). As examples of recent case studies, the refinement of the Harappa chronology (Agrawal and Kharakwal 2003) and the Neolithic time frame in southern India (Fuller et al. 2007) are notable.

\section{Africa}

The amount of ${ }^{14} \mathrm{C}$ dates produced for African prehistoric sites is relatively small compared to Europe and Asia. Most work was done for the area of Egypt, especially in terms of chronology of Egyptian pharaonic dynasties. As noted before, the very first sample dated by ${ }^{14} \mathrm{C}$ in 1948 came from Africa (Arnold and Libby 1949). Libby (1965:77-140) listed $34{ }^{14} \mathrm{C}$ values from Africa (mainly from the modern Republic of South Africa and Zimbabwe), including such important sites as Mufo (Late Stone Age), 11,200 BP; Zimbabwe [Great Zimbabwe] dated to 1360 BP (cal AD 550-810), which may correspond to the early phase of Zimbabwe tradition, AD 500-900 (Bahn 2001:173); Situmpa and Lusu sites with Bambata pottery dated to about 2140-1850 BP, while later studies gave ages of 2150-1800 BP (e.g. Mitchell 2002:233); and Bushman rock art from Phillip Cave dated to $\sim 3370 \mathrm{BP}$. All these early ${ }^{14} \mathrm{C}$ dates were generally confirmed afterwards (e.g. Mitchell 2002), except Great Zimbabwe, which was redated to the 14th century AD (see Robertshaw 1992:343). We can say that W F Libby and his colleagues laid the foundation for African prehistoric time frame in the late 1940s and early 1950s.

Egypt remains perhaps the best-studied region of Africa in terms of ${ }^{14} \mathrm{C}$ dating. The first results of age determinations made at the University of Chicago were received with enthusiasm (Braidwood et al. 1951; McBurney 1952). Further dating-for example, a piece of coffin wood from the tomb of pharaoh Tutankhamon [also "Tutankhamen" and "Tutankhamun"] - $2980 \pm 50$ BP (P-726) [Radiocarbon 7:196], corresponding to a calendar age of 1290-1130 cal BC (with $\pm 2 \sigma: 1380-1050$ cal BC)—confirmed the estimated "historic" date of 1343 BC. Samples with "known age" derived from Egyptian pharaonic monuments were crucial in the establishing the calibration of the ${ }^{14} \mathrm{C}$ time scale (see Berger 1992:431). The concerns about discrepancy between historic and ${ }^{14} \mathrm{C}$-derived chronologies expressed before the introduction of the calibration of ${ }^{14} \mathrm{C}$ dates (e.g. Smith 1964) were later solved (e.g. Mellaart 1979). Numerous papers related to Egyptian prehistoric chronologies were published from the 1970s onward (e.g. Hassan 1987). Ages of the Old and Middle Kingdom sites were established on the basis of more than $450{ }^{14} \mathrm{C}$ dates (Görsdorf et al. 1998; Bonani et al. 2001). A recent study of Roman and Coptic textiles (Van Strydonck et al. 2004) shows that the archaeological dates based on motifs, designs, and weaving technologies usually fits the ${ }^{14} \mathrm{C}$ ages on the order of 2 centuries. Extensive ${ }^{14} \mathrm{C}$ dating allowed to establish that some Egyptian pyramids at Giza, Sakkara [Saqqara], and Abu Roash are 300-400 yr older than accepted before, and they might have been built in Predynastic times. Also, the beginning of the Old Kingdom in Egypt occurred 300 yr earlier than it was believed. Large series of ${ }^{14} \mathrm{C}$ dates were obtained from the Wadi Kubbaniya site in southern Egypt (e.g. Wendorf et al. 1984), where direct AMS dating of carbonized barley grains allowed to reject the hypothesis of early cereal production in the Late Paleolithic (about 18,500-17,000 BP), and to conclude that the economy was of typical gathering, fishing, and hunting (Wendorf et al. 1984: 646). The latest summaries on achievements in prehistoric and early historic chronologies from Egypt are in volumes edited by Bar-Yosef and Kra (1994) and Bruins et al. (2001). 
Smith (1965:205) pointed out that the initial results of ${ }^{14} \mathrm{C}$ dating for African Paleolithic complexes brought important consequences: “...it now seems that the Upper Palaeolithic began much earlier than was suspected on the southern shore of the Mediterranean and its hinterland, possibly even earlier than in Western Europe, and such regions as Egypt were not entirely the isolated or culturally stagnant zones hitherto accepted. Much of this new outlook is the direct consequence of radiocarbon dating." In the 1960s, the first ${ }^{14} \mathrm{C}$ date series from several sites in east and south Africa, including Nachikufu and Kalambo Falls, were released [Radiocarbon 3:134-5; Radiocarbon 9:144-9; Radiocarbon 11:641-50]. One of the first summaries on Paleolithic ${ }^{14} \mathrm{C}$ dates in Africa was given by Vogel and Beaumont (1972). Stuiver and van der Merwe (1968) summarized early results of the ${ }^{14} \mathrm{C}$ dating of Iron Age complexes in sub-Saharan regions.

Further developments made since the late 1950s were put together in a comprehensive review by Clark (1979). He gave a general outline of the main chronocultural complexes in sub-Saharan and north Africa, such as the Middle/early Later Stone Age transition at 40,000 BP; the Late Stone Age (microlithic); Epi-Paleolithic; and the origin and spread of the Early Iron Age with animal herding. Also, Clark (1979:14-6) correlated these complexes with Europe and southwest Asia (Levant). The progress was summarized by Wendorf (1992) and Robertshaw (1992). In northern Africa, the transition from Middle Stone Age to Late Stone Age took place after $~ 40,000$ BP and before $~ 25,000$ BP. The very early age of art at Apollo 11 Cave in Namibia, 27,000 BP (e.g. Mitchell 2002:1323 ), is one of the most fascinating results of the application of ${ }^{14} \mathrm{C}$ dating to African prehistory.

As examples of the recent advanced application of ${ }^{14} \mathrm{C}$ dating method in the study of African prehistoric chronologies, 2 case studies should be mentioned. The first one regards the direct AMS ${ }^{14} \mathrm{C}$ dating of sheep bones in South Africa. Sealy and Yates (1994) redated important sites of Spoegrivier, Kasteelberg, De Kelders, and Byneskranskop in the southern and western Cape regions and in Namibia, and obtained ${ }^{14} \mathrm{C}$ ages that were mostly younger (about $1630-1330$ BP) compared to earlier dating of associated material (about 1960-1860 BP). Also, Inskeep and Vogel (1985) and Henshilwood (1995) contributed to the understanding of the Holocene cultural chronology of South Africa. The second case study is the establishment of the chronology for the Gombe Point site in the central part of the continent, now the Democratic Republic of Congo [Zaire]. Here, $25{ }^{14} \mathrm{C}$ dates were obtained from different cultural complexes, ranging from Paleolithic (about 46,500-37,500 BP) to Late Iron Age ( $200 \mathrm{BP})$ (Cahen et al. 1983). The most recent advancements in African prehistoric chronologies (besides Egypt) are presented in a volume edited by Évin et al. (1999:345-85, 465-6).

\section{CONTROVERSIAL ISSUES}

Ironically enough, one of the very first ${ }^{14} \mathrm{C}$ dates produced by W F Libby and his colleagues could be an error. It turns out that wood sample supplied by $\mathbf{J}$ Wilson from the presumably Hellenistic period (around half-age of wood from tomb of pharaoh Zoser) gave a nearly modern level of ${ }^{14} \mathrm{C}$ isotope activity (see Marlowe 1980:1012-3; Taylor 1987:164). Later, it was understood that the wood did not come from a reliable archaeological context but was acquired from an antiquities dealer in Egypt, and represents a modern fake.

The association of samples for ${ }^{14} \mathrm{C}$ dating and prehistoric events with assumed ages is a major problem. Often, the expected age is based on a wrong assumption, and the produced ${ }^{14} \mathrm{C}$ date at first glance looks unreliable, even ridiculous, and only after a re-evaluation of the initial provenance does a reasonable explanation arise for the difference between the expected and measured ages. For example, the supposed remains of Noah's Ark, collected on the slope of the Mount Ararat in modern 
Turkey, with the expected age of the biblical Flood at least $5000 \mathrm{yr}$ ago, were ${ }^{14} \mathrm{C}$ dated to about 1690-1190 BP with a tight cluster of 5 dates around 1350-1190 BP (Taylor and Berger 1980). The calendar ages of these ${ }^{14} \mathrm{C}$ values are around cal AD 600-960. The most reasonable explanation of this discrepancy is that material for dating was collected from "cenotaph or memorial [which] was erected by Armenian or Byzantine clerics to commemorate what they believed to be the location of the final resting place of the Ark of Noah. Perhaps this cenotaph was actually built in the form of a boat." (Taylor and Berger 1980:36).

A more serious issue is the "re-evaluation" of ${ }^{14} \mathrm{C}$ ages for some objects that were dated before, and for some reason, the results are not satisfactory for certain individuals and groups/organizations. One clear case is the attempt to reconsider the age of the famous Shroud of Turin, with a ${ }^{14} \mathrm{C}$ date originally measured as $\sim 690$ BP (cal AD 1260-1390) (Damon et al. 1989). A person named Dmitri A Kouznetsov claimed that his crew conducted "conventional AMS analysis" in order to examine the possible fire-induced chemical modifications of the textile cellulose using old examples of Russian and Middle Eastern linen textiles (Kouznetsov et al. 1996:109). It should be pointed out that in the 1990s and even until now, there are no AMS machines in Russia with known parameters that might have been used to measure the ${ }^{14} \mathrm{C}$ content in small samples of linen before and after temperature impact. The equipment employed by Kouznetsov et al. (1996:112), "The MK80 Mass Spectrometer (NPO Electron Instruments, Zelenograd, Russia)," is not suitable for standard AMS ${ }^{14} \mathrm{C}$ measurements.

This concern was raised among other problems by Jull et al. (1996) in their response to Kouznetsov et al. (1996). It was found that "even if the carbon displacements proposed by the authors during the heat treatment were correct, no significant change in the measured radiocarbon age of the linen would occur. We must conclude that the attack by Kouznetsov and his coworkers on measurements of the radiocarbon age of the Shroud of Turin and on radiocarbon measurements on linen textiles in general are unsubstantiated and incorrect." (Jull et al. 1996:160). It turned out that there are several unsubstantiated claims (articles in journals that do not exist, papers that do not appear where indicated, and samples of textile from several objects in Ireland that do not exist) made by Kouznetsov in the 1990s; this is vividly described by Meacham (2007). The performance of Kouznetsov et al. (1996) was at least an invalid experiment, and there is no reason to challenge results of the ${ }^{14} \mathrm{C}$ dating of the Shroud of Turin. Despite other negative opinions about the validity of dating of this worldknown relic (see review in Gove 1990), no one has so far proved scientifically that the age of the Shroud of Turin of $\sim 690 \mathrm{BP}$ is incorrect. The supposed enrichment of old textiles by younger ${ }^{14} \mathrm{C}$ isotope during heating, put forward by Kouznetsov et al. (1996), was never replicated (e.g. Jull et al. 1996; Long 1998).

As an example of using ${ }^{14} \mathrm{C}$ dating to detect archaeological frauds, the famous Piltdown forgery may be mentioned. This hoax was originally revealed in 1953 (e.g. Bahn 2001:358-9) and was later confirmed by ${ }^{14} \mathrm{C}$ dating of presumed very early hominid bones. A skull yielded a date of $\sim 620 \mathrm{BP}$ and a jaw bone of $~ 500$ BP [Radiocarbon 6:368], corresponding to calendar ages of cal AD 1290-1610. Another illustration comes from Japan, where ${ }^{14} \mathrm{C}$ dating of tephra layers at some supposed Early and Middle Paleolithic sites was performed (Nagamoto et al. 1999). Soon after publication of this paper, the large-scale fraud was discovered in November 2000 at these sites (e.g. Keally 2002), and it turned out that tephras' ${ }^{14} \mathrm{C}$ ages have nothing to do with occurrences of Paleolithic artifacts. 


\section{CONCLUSION}

The refinement of regional prehistoric chronological schemes seems to be an endless process, with more-or-less significant changes in the approaches and paradigms every 1 or 2 decades. Nevertheless, many research problems that existed before still stand today. However, I am confident that the future of archaeological chronology is secure when the ${ }^{14} \mathrm{C}$ dating is correctly applied along with other lines of evidence. The openness of results and confirmation of important dates in several independent laboratories should be rule for the 21 st century and onward. Creative collaboration between archaeologists and ${ }^{14} \mathrm{C}$ specialists is the key to any progress in the field of prehistoric time frames. As it was absolutely correctly mentioned, "Successful application of ${ }^{14} \mathrm{C}$ dating requires detailed consideration of the many complex requirements which must be met to satisfy the assumptions underlying the method. While some of these requirements are the sole responsibility of the ${ }^{14} \mathrm{C}$ laboratory, most are not, and they must be carefully evaluated by the archaeological user if reliable chronological information is to be obtained. In particular, the archaeologist must carefully specify the chronological questions of interest, and must then carefully identify, choose and evaluate samples which can be expected to provide reliable answers to those questions. This is not a task which can simply be delegated to the 'scientific experts' at the measurement laboratory, but it is also the responsibility of the user" (Van Strydonck et al. 1999:440). This lengthy quotation reflects, in my opinion, the optimal relationship between "makers" and "users" of chronological information.

\section{ACKNOWLEDGMENTS}

I am grateful to A J Timothy Jull and Mark E McClure for the invitation to participate in this volume. While collecting information for this paper in early to mid-2008, various kinds of support were provided by G S Burr, A J Timothy Jull, Mitzi de Martino, Tatiana M Karafet, and Mark E McClure (University of Arizona, Tucson, Arizona, USA); and Richard L Bland (University of Oregon, Eugene, Oregon, USA). I am indebted to several colleagues who for years supplied me with rare offprints, especially from Oriental sources. I am pleased to thank Prof Ofer Bar-Yosef (Harvard University, Cambridge, Massachusetts, USA) and an anonymous reviewer for checking the draft of this paper and making useful suggestions. This research was partly funded by the Russian Foundation for Basic Sciences (RFFI), grants 06-06-80258 and 09-06-00126.

\section{REFERENCES}

Abramova ZA, Grigorieva GV, Zaitseva GI. 2001. The age of Upper Paleolithic sites in the Middle Dnieper River basin of eastern Europe. Radiocarbon 43(2B): 1077-84.

Ackerman RE. 1982. The Neolithic-Bronze Age cultures of Asia and the Norton phase of Alaskan prehistory. Arctic Anthropology 19(2):11-38.

Agrawal DP. 1965. $\mathrm{C}^{14}$ dates, Banas culture and the Aryans. In: Chatters RM, Olson EA, editors. Proceedings of the Sixth International Conference "Radiocarbon and Tritium Dating." Springfield, Virginia, USA: Clearinghouse for Federal Scientific and Technical Information. p 256-63.

Agrawal DP, Kharakwal JS. 2002. South Asian Prehistory: A Multidisciplinary Study. New Delhi: Arian Books International. 268 p.

Agrawal DP, Kharakwal JS. 2003. Bronze and Iron Ages in South Asia. New Delhi: Arian Books International. 322 p.
Aikens CM, Higuchi T. 1982. Prehistory of Japan. San Diego: Academic Press. 354 p.

Aitken MJ. 1990. Science-Based Dating in Archaeology. London: Longman. 274 p.

Aldhouse-Green S. 1998. Paviland Cave: contextualizing the 'Red Lady.' Antiquity 72(278):756-63.

Alekseev AYu, Bokovenko NA, Boltrik Yu, Chugunov KV, Cook G, Dergachev VA, Kovalyukh N, Possnert G, van der Plicht J, Scott EM, Sementsov A, Skripkin V, Vasiliev S, Zaitseva G. 2001. A chronology of the Scythian antiquities of Eurasia based on new archaeological and ${ }^{14} \mathrm{C}$ data. Radiocarbon 43(2B):1085-107.

Ambers J. 1998. Dating Grimes Graves. Radiocarbon 40(2):591-600.

An Z. 1989. Application of ${ }^{14} \mathrm{C}$ dating to the Early Neolithic in South China. Di Si Ji Yanjiu 6(2):123-33. In Chinese with English abstract.

An Z. 1991. Radiocarbon dating and the prehistoric archaeology of China. World Archaeology 23(2):193-200. 
Anderson DD. 1997. Cave archaeology in Southeast Asia. Geoarchaeology 12(6):607-38.

Anikovich MV. 2005. About the chronology of the Kostenki-Boshchevo region. Archaeology, Ethnology \& Anthropology of Eurasia 6(3)[No. 23]:70-86.

Arnold JR, Libby WF. 1949. Age determinations by radiocarbon content: checks with samples of known age. Science 110(2869):678-80.

Aurenche O, Galet P, Régagnon-Caroline E, Évin J. 2001. Proto-Neolithic and Neolithic cultures in the Middle East - the birth of agriculture, livestock raising, and ceramics: a calibrated ${ }^{14} \mathrm{C}$ chronology 12,500-5500 cal BC. Radiocarbon 43(3):1191-202.

Bae KD, Kim JC. 2003. Radiocarbon chronology of the Palaeolithic complexes and the transition to the Neolithic in Korea. The Review of Archaeology 24(2): 46-9.

Bahn P, editor. 2001. The Penguin Archaeology Guide. London: Penguin Books. 494 p.

Balter M. 2008. Going deeper into the Grotte Chauvet. Science 321(5891):904-5.

Bandi H-G. 1965. C ${ }^{14}$ dates from Mesolithic sites in Central Europe. In: Chatters RM, Olson EA, editors. Proceedings of the Sixth International Conference "Radiocarbon and Tritium Dating." Springfield, Virginia, USA: Clearinghouse for Federal Scientific and Technical Information. p 225-31.

Banks WE, d'Errico F, Peterson AT, Vanhaeren M, Kageyama M, Sepulchre P, Ramstein G, Jost A, Lunt D. 2008. Human ecological niches and ranges during the LGM in Europe derived from an application of eco-cultural niche modeling. Journal of Archaeological Science 35(2):481-91.

Bar-Yosef O. 2000. The impact of radiocarbon dating on Old World archaeology: past achievements and future expectations. Radiocarbon 42(1):23-39.

Bar-Yosef O, Kra RS, editors. 1994. Late Quaternary Chronology and Paleoclimates of the Eastern Mediterranean. Tucson, Arizona, USA: Radiocarbon. 371 p.

Bar-Yosef O, Arnold M, Mercier N, Belfer-Cohen A, Goldberg P, Housley R, Laville H, Meignen L, Vogel JC, Vandermeersch B. 1996. The dating of the Upper Paleolithic layers in Kebara Cave, Mt Carmel. Journal of Archaeological Science 23(2):297-306.

Barker G, Reynolds T, Gilbertson D. 2005. The human use of caves in peninsular and island Southeast Asia: research themes. Asian Perspectives 44(1):1-15.

Barnard N. 1972. The First Radiocarbon Dates from China. Monographs on Far Eastern History No. 8. Canberra: Australian National University. 33 p.

Barram A. 2003. Dating "Dvaravati." Bulletin of the Indo-Pacific Prehistory Association 23:59-62.

Barton L, Brantingham PJ, Ji D. 2007. Late Pleistocene climate change and Paleolithic cultural evolution in northern China: implications from the Last Glacial Maximum. In: Madsen DB, Chen FH, Gao X, editors. Late Quaternary Climate Change and Human Adaptation in Arid China. Amsterdam: Elsevier. p 105-28.
Bayard DT. 1972. Early Thai bronze: analysis and new dates. Science 176(4042):1411-2.

Bayliss A, Groves C, McCormac G, Baillie M, Brown D, Brennand M. 1999. Precise dating of the Norfolk timber circle. Nature 402(6761):479.

Bellwood P, Gillespie R, Thomson GB, Vogel JS, Ardika IW, Datan I. 1992. New dates for prehistoric Asian rice. Asian Perspectives 31(2):161-70.

Berger R. 1992. Libby's UCLA radiocarbon laboratory: contributions to archaeology. In: Taylor RE, Long A, Kra RS, editors. Radiocarbon After Four Decades: An Interdisciplinary Perspective. New York: SpringerVerlag; Tucson: Radiocarbon. p 421-34.

Berger R, Protsch R. 1989. UCLA radiocarbon dates XI. Radiocarbon 31(1):55-67.

Berstan R, Stott AW, Minnitt S, Bronk Ramsey C, Hedges REM, Evershed RP. 2008. Direct dating of pottery from its organic residues: new precision using compound-specific carbon isotopes. Antiquity 82(317):702-13.

Bishop P, Sanderson DCW, Stark MT. 2004. OSL and radiocarbon dating of a pre-Angkorian canal in the Mekong delta, southern Cambodia. Journal of Archaeological Science 31(3):319-36.

Blackwell PG, Buck CE. 2003. The Late Glacial human reoccupation of north-western Europe: new approaches to space-time modelling. Antiquity 77(296): 232-40.

Bocquet-Appel J-P, Demars P-Y, Noiret L, Dobrowsky D. 2005. Estimates of Upper Palaeolithic meta-population size in Europe from archaeological data. Journal of Archaeological Science 32(11):1656-68.

Bonani G, Ivy S, Wölfli W, Broshi M, Carmi I, Strugnell J. 1992. Radiocarbon dating of fourteen Dead Sea Scrolls. Radiocarbon 34(3):843-9.

Bonani G, Haas H, Hawass Z, Lehner M, Nakhla S, Nolan J, Wenke R, Wölfli W. 2001. Radiocarbon dates of Old and Middle Kingdom monuments in Egypt. $R a$ diocarbon 43(3):1297-320.

Bonsall C, Cook GT, Hedges REM, Higham TFG, Pickard C, Radovanović I. 2004. Radiocarbon and stable isotope evidence of dietary change from the Mesolithic to the Middle Ages in the Iron Gates: new results from Lepenski Vir. Radiocarbon 46(1):293-300.

Borić D, Miracle P. 2004. Mesolithic and Neolithic (dis)continuities in the Danube Gorges: new AMS dates from Padina and Hajdučka Vodenica (Serbia). Oxford Journal of Archaeology 23(4):341-71.

Borodovsky AP, Slusarenko IY, Kuzmin YV, Orlova LA, Christen JA, Garkusha YN, Burr GS, Jull AJT. 2003. Chronology of Early Iron Age burial assemblages in the Upper Ob region based on the tree-ring and radiocarbon methods: Bystrovka-2 burial ground. Archaeology, Ethnology \& Anthropology of Eurasia 4(3)[No. 15]:79-92.

Brantingham PJ, Kuhn SL, Kerry KW, editors. 2004. The Early Upper Paleolithic Beyond Western Europe. Berkeley: University of California Press. 295 p. 
Brock F, Bronk Ramsey C, Higham T. 2007. Quality assurance of ultrafiltered bone dating. Radiocarbon 49(2):187-92.

Bronk Ramsey C, Manning SW, Galimberti M. 2004. Dating the volcanic eruption at Thera. Radiocarbon 46(1):325-44.

Brown A. 2007. Dating the onset of cereal cultivation in Britain and Ireland: the evidence from charred cereal grains. Antiquity 81(314):1042-52.

Bruins H, van der Plicht J. 1996. The Exodus enigma. Nature 382(6588):213-4.

Bruins H, Carmi I, Boaretto E, editors. 2001. Near East Chronology: Archaeology and Environment (special issue). Radiocarbon 43(3):1147-390.

Burleigh R. 1981. W.F. Libby and the development of radiocarbon dating. Antiquity 55(214):96-8.

Buvit I, Terry K, Konstantinov AV, Konstantinov MV. 2004. Studenoe 2: an update. Current Research in the Pleistocene 21:1-3.

Cahen D, Moeyersons J, Mook WG. 1983. Radiocarbon dates from Gombe Point (Kinshasa, Zaïre) and their implications. In: Mook WG, Waterbolk HT, editors. Proceedings of the First International Symposium "14C and Archaeology" (PACT No. 8). Strasbourg: Council of Europe. p 441-52.

Chakrabarti DK. 2006. The Oxford Companion to Indian Archaeology. New Delhi: Oxford University Press. $570 \mathrm{p}$.

Chang KC. 1973. Radiocarbon dates from China: some initial interpretations. Current Anthropology 14:525-

Chang KC. 1986. The Archaeology of Ancient China. 4th edition. New Haven: Yale University Press. 450 p.

Chard CS. 1962. First radiocarbon dates from the U.S.S.R. Arctic Anthropology 1(1):84-6.

Chard CS. 1973. Northeast Asia in Prehistory. Madison: University of Wisconsin Press. 214 p.

Chernykh EN. 2008. The formation of Eurasian "steppe belt" stockbreeding cultures: view through the prism of archaeometallurgy and radiocarbon dating. Archaeology, Ethnology \& Anthropology of Eurasia 35/3:3653

Chernykh EN, Avilova LI, Orlovskaya LB. 2000. Metallurgical Provinces and Radiocarbon Chronology. Moscow: Institute of Archaeology, Russian Academy of Sciences. 95 p. In Russian and English.

Choe PC, Bale MT. 2002. Current perspectives on settlement, subsistence, and cultivation in prehistoric Korea. Arctic Anthropology 39(1-2):95-121.

Clark JD. 1979. Radiocarbon dating and African archaeology. In: Berger R, Suess HE, editors. Radiocarbon Dating. Berkeley: University of California Press. p $7-$ 31

Clark JGD. 1965. Radiocarbon dating and expansion of farming from the Near East over Europe. Proceedings of the Prehistoric Society 31:57-73.

Conard NJ, Bolus M. 2003. Radiocarbon dating the ap- pearance of modern humans and timing of cultural innovations in Europe: new results and new challenges. Journal of Human Evolution 44(3):331-71.

Conard NJ, Grootes PM, Smith FH. 2004. Unexpectedly recent dates for human remains from Vogelherd. $\mathrm{Na}$ ture 430(6996): 198-201.

Crawford GW, Shen C. 1998. The origins of rice agriculture: recent progress in East Asia. Antiquity 72(278): 858-66.

Crawford OGS. 1949. Editorial notes. Antiquity 23(91): 113-4.

Cuzange M-T, Delqué-Količ E, Goslar T, Grootes PM, Higham T, Kaltnecker E, Nadeau M-J, Oberlin C, Paterne $\mathrm{M}$, van der Plicht J, Bronk Ramsey C, Valladas H, Clottes J, Geneste J-M. 2007. Radiocarbon intercomparison program for Chauvet Cave. Radiocarbon 49(2):339-47.

Dai K, Qian Y, Zhang Z. 1990. ${ }^{14} \mathrm{C}$ dating and archaeology in China. In: Mook WG, Waterbolk HT, editors. Proceedings of the Second International Symposium "14 C and Archaeology" (PACT No. 29). Strasbourg: Council of Europe. p 305-9.

Damblon F, Haesaerts P, van der Plicht J. 1996. New datings and considerations on the chronology of Upper Palaeolithic sites in the Great Eurasian Plain. Préhistoire Européenne 9:177-231.

Damon PE, Donahue DJ, Gore BH, Hatheway AL, Jull AJT, Linick TW, Sercel PJ, Toolin LJ, Bronk CR, Hall ET, Hedges REM, Housley R, Law IA, Perry C, Bonani G, Trumbore S, Woelfli W, Ambers JC, Bowman SGE, Leese MN, Tite MS. 1989. Radiocarbon dating of the Shroud of Turin. Nature 337(6208):611-5.

Davison K, Dolukhanov PM, Sarson GR, Shukurov A, Zaitseva GI. 2007. A pan-European model of the Neolithic. Documenta Praehistorica 34:139-54.

d'Errico F, Goñi MFS. 2003. Neanderthal extinction and the millennial scale climatic variability of OIS 3. Quaternary Science Reviews 22(8-9):769-88.

Derevianko AP. 2001. The Middle to Upper Paleolithic transition in the Altai (Mongolia and Siberia). Archaeology, Ethnology \& Anthropology of Eurasia 2(3)[No. 7]:70-103.

Derevianko AP, Gladyshev SA, Nohrina TI, Olsen JW. 2003. The Mongolian Early Holocene: excavations at Chikhen Agui rockshelter in the Gobi Altai. The Review of Archaeology 24(2):50-6.

Dergachev VA, Vasiliev SS, Sementsov AA, Zaitseva GI, Chugunov KA, Sljusarenko IJ. 2001. Dendrochronology and radiocarbon dating methods in archaeological studies of Scythian sites. Radiocarbon 43(2A):41724.

Dincauze DF. 2000. Environmental Archaeology: Principles and Practice. Cambridge: Cambridge University Press. 587 p.

Djindjan F. 1999. Datations ${ }^{14} \mathrm{C}$ du Paléolitique Supérior Européen: bilan et perspectives. Mémoires de la Societé Préhistorique Française 26:171-9. In French. 
Dolukhanov PE, Timofeev VI. 1972. Absolyutnaya khronologiya neolita Evrazii (po dannym radiouglerodnogo metoda) [Absolute chronology of the Neolithic of Eurasia (based on data by radiocarbon method)]. In: Kolchin BA, editor. Problemy Absolyutnogo Datirovaniya v Arkheologii. Moscow: Nauka Publishing. p 28-75. In Russian.

Dolukhanov PM, Shukurov AM, Tarasov PE, Zaitseva GI. 2002. Colonization of northern Eurasia by modern humans: radiocarbon chronology and environment. Journal of Archaeological Science 29(6):593-606.

Dolukhanov P, Shukurov A, Gronenborn D, Sokoloff DD, Timofeev VI, Zaitseva GI. 2005. The chronology of Neolithic dispersal in Central and Eastern Europe. Journal of Archaeological Science 32(10):1441-58.

Donahue DJ, Olin JS, Harbottle G. 2002. Determination of the radiocarbon age of parchment of the Vinland Map. Radiocarbon 44(1):45-52.

Dumond DE, Bland RL. 1995. Holocene prehistory of the northernmost North Pacific. Journal of World Prehistory 9(4):401-51.

Dunn FL. 1966. Radiocarbon dating of the Malayan Neolithic. Proceedings of the Prehistoric Society 32: 352-3.

Ehrich RW, editor. 1992. Chronologies in Old World Archaeology. 3rd edition. Volume I. 515 p. Volume II. 588 p. Chicago: University of Chicago Press.

Évin J, Oberlin C, Daugas J-P, Salles J-F, editors. 1999. ${ }^{14} \mathrm{C}$ et Archéologie $\left({ }^{14} \mathrm{C}\right.$ and Archaeology). Mémoires de la Societé Préhistorique Française Tome 26. Rennes: Université de Rennes. 478 p.

Fagan BM, editor. 1996. The Oxford Companion to Archaeology. New York: Oxford University Press. $844 \mathrm{p}$.

Fairweather AD, Ralston IBM. 1993. The Neolithic timber hall at Balbridie, Grampian Region, Scotland: the building, the date, the plant macrofossils. Antiquity 67(255):313-23.

Fiedel SJ, Kuzmin YV. 2007. Radiocarbon date frequency as an index of intensity of Paleolithic occupation of Siberia: did humans react predictably to climate oscillations? Radiocarbon 49(2):741-56.

Finkelstein I, Piasetzky E. $2006 .{ }^{14} \mathrm{C}$ and the Iron Age chronology debate: Rehov, Khirbet en-Nahas, Dan, and Megiddo. Radiocarbon 48(2):373-86.

Finlayson C, Fa DA, Jiménez Espejo F, Carrión JS, Finlayson G, Giles Pacheco F, Rodríguez Vidal J, Stringer C, Martínez Ruiz F. 2008. Gorham's Cave, Gibraltar-the persistence of a Neanderthal population. Quaternary International 181(1):64-71.

Fischer A, Kristiansen K, editors. 2002. The Neolithisation of Denmark: 150 Years of Debate. Sheffield: J.R. Collins. 398 p.

Fitzhugh B, Shubin VO, Tezuka K, Ishizuka Y, Mandryk CAS. 2002. Archaeology in the Kuril Islands: advances in the study of human paleobiogeography and Northwest Pacific prehistory. Arctic Anthropology 39(1-2):69-94.
Fitzhugh WW, Ward EI, editors. 2000. Vikings: The North Atlantic Saga. Washington, DC: Smithsonian Institution Press. 432 p.

Forenbaher S, Miracle PT. 2005. The spread of farming in the eastern Adriatic. Antiquity 79(305):514-28.

Fuller DQ, Boivin N, Korisettar R. 2007. Dating the Neolithic of South India: new radiometric evidence for key economic, social and ritual transformations. Antiquity 81(313):755-78.

Gamble C, Davies W, Pettitt P, Hazelwood L, Richards M. 2005. The archaeological and genetic foundations of the European population during the Late Glacial: implications for 'agricultural thinking.' Cambridge Archaeological Journal 15(2):193-223.

Gkiasta M, Russell T, Shennan S, Steele J. 2003. Neolithic transition in Europe: the radiocarbon record revisited. Antiquity 77(295):45-62.

Goebel T. 1999. Pleistocene human colonization of Siberia and peopling of the Americas: an ecological approach. Evolutionary Anthropology 8(6):208-27.

Goebel T, Aksenov M. 1995. Accelerator radiocarbon dating of the initial Upper Palaeolithic in southeast Siberia. Antiquity 69(263):349-57.

Goebel T, Slobodin SB. 1999. The colonization of western Beringia: technology, ecology, and adaptations. In: Bonnichsen R, Turnmire KL, editors. Ice Age People of North America: Environment, Origins, and Adaptations. Corvallis: Oregon State University Press. p 104-55.

Goebel T, Derevianko AP, Petrin VT. 1993. Dating the Middle-to-Upper Paleolithic transition at Kara-Bom. Current Anthropology 34(4):452-8.

Goebel T, Waters MR, Buvit I, Konstantinov MV, Konstantinov AV. 2000. Studenoe-2 and the origins of microblade technologies in the Transbaikal, Siberia. Antiquity 74(285):567-75.

Goebel T, Waters MR, Dikova M. 2003. The archaeology of Ushki Lake, Kamchatka, and the Pleistocene peopling of the Americas. Science 301(5632):501-5.

Gorman CF. 1969. Hoabinian: a pebble-tool complex with early plant associations in Southeast Asia. Science 163(3868):671-3.

Görsdorf J, Dreyer G, Hartung U. 1998. New ${ }^{14} \mathrm{C}$ dating of the archaic royal necropolis Umm el-Qaab at Abydos (Egypt). Radiocarbon 40(2):641-7.

Görsdorf J, Parzinger H, Nagler A. 2001. New radiocarbon dates of the North Asian Steppe Zone and its consequences for the chronology. Radiocarbon 43(2B): 1115-20.

Gove HE. 1990. Dating the Turin shroud-an assessment. Radiocarbon 32(1):87-92.

Graf KE. 2005. Abandonment of the Siberian mammothsteppe during the LGM: evidence from the calibration of ${ }^{14} \mathrm{C}$-dated archaeological occupations. Current Research in the Pleistocene 22:2-5.

Graf KE. 2009. "The Good, the Bad, and the Ugly": evaluating the radiocarbon chronology of the middle and 
late Upper Paleolithic in the Enisei River valley, south-central Siberia. Journal of Archaeological Science 36(3):694-707

Grave P, Barbetti M. 2002. Dating the city wall, fortifications, and the palace site at Pagan. Asian Perspectives 40(1):75-87.

Gravina B, Mellars P, Bronk Ramsey C. 2005. Radiocarbon dating of interstratified Neanderthal and early modern human occupations at the Chatelperronian type-site. Nature 438(7064):51-6.

Griffin JB. 1949. $C^{14}$ dates. American Antiquity 15:80.

Gronenborn D. 1999. A variation of a basic theme: the transition to farming in southern Central Europe. Journal of World Prehistory 13(2):123-210.

Guo Z, Liu K, Lu X, Ma H, Li K, Yuan S, Wu X. 2000 The use of AMS radiocarbon dating for Xia-ShangZhou chronology. Nuclear Instruments and Methods in Physics Research B 172(1-4):724-31.

Habu J. 2004. Ancient Jomon of Japan. Cambridge: Cambridge University Press. 332 p.

Hall ME. 1997. Toward an absolute chronology for the Iron Age of Inner Asia. Antiquity 71(274):863-74.

Harris DR, Gosden C, Charles MP. 1996. Jeitun: recent excavations of the Early Neolithic site in southern Turkmenistan. Proceedings of the Prehistoric Society 62:423-42.

Harrisson T. 1958. Carbon-14 dated palæoliths from Borneo. Nature 181(4611):792.

Harrisson T. 1973. Carbon-14 dates from Kota Batu, Brunei (Borneo). Asian Perspectives 16(2):197-9

Harrisson T. 1975. Early dates for 'seated' burial and burial matting at Niah caves, Sarawak, Borneo. Asian Perspectives 18(2):161-5.

Hassan FA. 1987. High-precision radiocarbon chronometry of ancient Egypt, and comparisons with Nubia, Palestine and Mesopotamia. Antiquity 61(231):119 35.

Henry DO. 1992. The impact of radiocarbon dating on Near Eastern prehistory. In: Taylor RE, Long A, Kra RS, editors. Radiocarbon After Four Decades: An Interdisciplinary Perspective. New York: Springer-Verlag; Tucson: Radiocarbon. p 324-34.

Henshilwood C. 1995. A revised chronology for pastoralism in the southernmost Africa: new evidence of sheep at c. 2000 BP from Blombos Cave, South Africa. Antiquity 70(270):945-9.

Higham CFW. 1987. Chronology, evolution and diffusion of the later Southeast Asian cultural sequence: further comments. Bulletin of the Indo-Pacific Prehistory Association 7:141-7.

Higham C. 1989. The Archaeology of Mainland Southeast Asia: From 10,000 B.C. to the Fall of Angkor. Cambridge: Cambridge University Press. 387 p.

Higham C, Higham T. 2009. A new chronological framework for prehistoric Southeast Asia, based on a Bayesian model from Ban Non Wat. Antiquity 83(329): $125-44$.
Higham T, Bronk Ramsey C, Karavanić I, Smith FH, Trinkaus E. 2006a. Revised direct radiocarbon dating of the Vindija $\mathrm{G}_{1}$ Upper Paleolithic Neandertals. Proceedings of the National Academy of Sciences of the USA 103(3):553-7.

Higham TFG, Jacobi RM, Bronk Ramsey C. 2006b. AMS radiocarbon dating of ancient bone using ultrafiltration. Radiocarbon 48(2):179-95.

Hillman G, Hedges R, Moore A, Colledge S, Pettitt P. 2001. New evidence of Lateglacial cereal cultivation at Abu Hureyra on the Euphrates. The Holocene 11(4): 383-93.

Hoffecker JF. 2002. Desolate Landscapes: Ice-Age Settlement in Eastern Europe. New Brunswick: Rutgers University Press. 298 p.

Housley RA, Glamble CS, Street M, Pettitt P. 1997. Radiocarbon evidence for the Lateglacial human recolonization of northern Europe. Proceedings of the Prehistoric Society 63:25-54.

Hudson B, Lwin N, Maung (Tanpawady) W. 2002. The origins of Bagan: new dates and old inhabitants. Asian Perspectives 40(2):48-74.

Hurley W, Ralph E, Han M, Yoshizaki M. 1976. The chronometric gap from Early Jomon in southern Hokkaido: a radiocarbon and thermoluminescence view. Asian Perspectives 19(1):116-44.

Ikawa F. 1964. The continuity of non-ceramic to ceramic cultures in Japan. Arctic Anthropology 2(2):95-119.

Ikawa-Smith F. 1976. Chronological framework for the study of the Palaeolithic in Japan. Asian Perspectives 19(1):61-90.

Imamura K. 1996. Prehistoric Japan. New Perspectives on Insular East Asia. Honolulu: University of Hawaii Press. $246 \mathrm{p}$

Inskeep RR, Vogel JC. 1985. Radiocarbon dates for the Holocene levels at Nelson Bay cave, and an interim report of their association. South African Archaeological Bulletin 40:103-5.

Institute of Archaeology of the Chinese Academy of Social Sciences. 1991. Radiocarbon Dating in Chinese Archaeology, 1965-1991. Edited by the Institute of Archaeology, Chinese Academy of Social Sciences. Beijing: Cultural Relics Publishers. In Chinese with English abstract. $487 \mathrm{p}$.

Jelinek AJ. 1962. An index of radiocarbon dates associated with cultural materials. Current Anthropology 3(5):451-77.

Jennings JD, editor. 1951. Radiocarbon Dating: A Report on the Program to Aid in the Development of the Method of Dating. Memoirs of the Society for American Archaeology No. 8. Salt Lake City: Society for American Archaeology. 65 p.

Johnson F. 1965. Reflections upon the significance of radiocarbon dates. In: Libby WF. Radiocarbon Dating. 2nd edition. Chicago: Phoenix Books. p 141-61.

Jull AJT, Donahue DJ, Broshi M, Tov E. 1995. Radiocarbon dating of scrolls and linen fragments from the 
Judean Desert. Radiocarbon 37(1):11-9.

Jull AJT, Donahue DJ, Damon PE. 1996. Factors affecting the apparent radiocarbon age of textiles: a comment on "Effects of fires and biofractionation of carbon isotopes on results of radiocarbon dating of old textiles: the Shroud of Turin," by D.A. Kouznetsov et al. Journal of Archaeological Science 23(1):157-60.

Keally CT. 2002. Japan's Early-Palaeolithic hoax and two sites. Current Research in the Pleistocene 19:469.

Keally CT. 2004. Bad science and the distortion of history: radiocarbon dating in Japanese archaeology. Sophia International Review 26:1-16.

Keally CT, Muto Y. 1982. Jomon jidai no nendai [Dating of the Jomon period]. In: Kato S, Kobayashi T, Fujimoto T, editors. Jomon Bunka no Kenkyu. Volume 1. Tokyo: Yuzankaku Publ. p 246-75. In Japanese.

Keally CT, Taniguchi Y, Kuzmin YV, Shewkomud IY. 2004. Chronology of the beginning of pottery manufacture in East Asia. Radiocarbon 46(1):345-51.

Keates SG, Hodgins GWL, Kuzmin YV, Orlova LA. 2007. First direct dating of a presumed Pleistocene hominid from China: AMS radiocarbon age of a femur from the Ordos Plateau. Journal of Human Evolution 53(1):1-5.

Kim H, Choo Y, Nah K. 1993. Radiocarbon dating and high-precision bidecadal calibration: calibration of Korean ${ }^{14} \mathrm{C}$ dates for Northeast Asian archaeological studies. Hanguk Koko Hakbo 30:5-61. In Korean with English title.

Kim IC, Kim JC, Park JH, Young MY, Kim SB, Lee ES. 2004. Dating the king's tombs of the Kingdom of Old Shilla, Korea. In: Higham T, Bronk Ramsey C, Owen C, editors. Radiocarbon and Archaeology. Oxford: Oxford University School of Archaeology. p 185-92.

Kislev M, Hartmann A, Bar-Yosef O. 2006. Early domesticated fig in the Jordan Valley. Science 312(5778): 1372-4.

Klein RG. 1967. Radiocarbon dates on occupation sites of Pleistocene age in the U.S.S.R. Arctic Anthropology 4(2):224-6.

Kouznetsov DA, Ivanov AA, Veletsky PR. 1996. Effects of fires and biofractionation of carbon isotopes on results of radiocarbon dating of old textiles: the Shroud of Turin. Journal of Archaeological Science 23(1): $109-21$.

Kovalyukh N, van der Plicht J, Possnert G, Skripkin V, Chlenova L. 2001. Dating of ancient icons from Kiev art collections. Radiocarbon 43(2B): 1065-75.

Krajcar Bronić I, Minichreiter K, Obelić B, Horvatinčić N. 2004. The oldest Early Neolithic (Starčevo culture) settlements in Croatia: Zadubravlje-Duźine and Slavonski Brod-Galovo. In: Higham T, Bronk Ramsey C, Owen C, editors. Radiocarbon and Archaeology. Oxford: Oxford University School of Archaeology. p 229-45.

Krause J, Orlando L, Serre D, Viola B, Prüfer K, Richards MP, Hublin J-J, Hänni C, Derevianko AP, Pääbo
S. 2007. Neanderthals in Central Asia and Siberia. $\mathrm{Na}$ ture 449(7164):902-4.

Krivoshapkin AI, Anoikin AA, Brantingham PJ. 2006. The lithic industry of Obi-Rakhmat grotto, Uzbekistan. Bulletin of the Indo-Pacific Prehistory Association 26:5-19.

Kuzmin YV. 2000. Radiocarbon chronology of the Stone Age cultures on the Pacific coast of Northeastern Siberia. Arctic Anthropology 37(1):120-31.

Kuzmin YV. 2006a. Chronology of the earliest pottery in East Asia: progress and pitfalls. Antiquity 80(308): $362-71$.

Kuzmin YV. 2006b. Palaeoenvironment and chronology. In: Nelson SM, Derevianko AP, Kuzmin YV, Bland RL, editors. Archaeology of the Russian Far East: Essays in Stone Age Prehistory. BAR International Series 1540. Oxford: Archaeopress. p 13-40.

Kuzmin YV. 2007. Chronological framework of the Siberian Paleolithic: recent achievements and future directions. Radiocarbon 49(2):757-66.

Kuzmin YV, Keates SG. 2005. Dates are not just data: Paleolithic settlement patterns in Siberia derived from radiocarbon records. American Antiquity 70(4):77389.

Kuzmin YV, Orlova LA. 2000. The Neolithization of Siberia and the Russian Far East: radiocarbon evidence. Antiquity 74(284):356-64.

Kuzmin YV, Tankersley KB. 1996. The colonization of Eastern Siberia: an evaluation of the Paleolithic age radiocarbon dates. Journal of Archaeological Science 23(4):577-85.

Kuzmin YV, Vetrov VM. 2007. The earliest Neolithic complex in Siberia: the Ust-Karenga 12 site and its significance for the Neolithisation process in Eurasia. Documenta Praehistorica 34:9-20.

Kuzmin YV, Burr GS, Jull AJT, Sulerzhitsky LD. 2004a. AMS ${ }^{14} \mathrm{C}$ age of the Upper Palaeolithic skeletons from Sungir site, Central Russian Plain. Nuclear Instruments and Methods in Physics Research B 223-224: $731-4$.

Kuzmin YV, Jull AJT, Razgildeeva II. 2004b. Chronology of the Upper-Paleolithic site Studenoe 2 (Transbaikal, Siberia): case study of the multi-hearth dwelling in horizon 4/5. Current Research in the Pleistocene 21:6-7.

Kuzmin YV, Slusarenko IY, Hajdas I, Bonani G, Christen JA. $2004 \mathrm{c}$. The comparison of ${ }^{14} \mathrm{C}$ wiggle-matching results for the 'floating' tree-ring chronology of the Ulandryk-4 burial ground (Altai Mountains, Siberia). Radiocarbon 46(2):943-8.

Kuzmin YV, Lbova LV, Jull AJT, Cruz RJ. 2006. The Middle-to-Upper-Paleolithic transition in Transbaikal, Siberia: the Khotyk site chronology and archaeology. Current Research in the Pleistocene 23: 43-6.

Kuzmina EE. 2008. The Prehistory of the Silk Road. Philadelphia: University of Pennsylvania Press. 248 p.

Lampert CD, Glover IC, Hedges REM, Heron CP, 
Higham TFG, Stern B, Shoocongdej R, Thompson GB. 2003. Dating resin coating on pottery: the Spirit Cave early ceramic dates revised. Antiquity 77(295): 126-33.

Lee YK. 2002. Building the chronology of early Chinese history. Asian Perspectives 41(1):15-42.

Leong SH. 2000. The chronology of the Bernam cist graves in peninsular Malaysia. Bulletin of the IndoPacific Prehistory Association 19:65-72.

Levine M, Kislenko AM. 1997. New Eneolithic and Early Bronze Age radiocarbon dates for north Kazakhstan and south Siberia. Cambridge Archaeological Journal 7(2):297-300.

Levy TE, Higham T, editors. 2005. The Bible and Radiocarbon Dating: Archaeology, Text and Science. London: Equinox. 450 p.

Libby WF. 1965. Radiocarbon Dating. 2nd edition. Chicago: Phoenix Books. 161 p.

Libby WF. 1980. Archaeology and radiocarbon dating. Radiocarbon 22(4):1017-20.

Libby WF, Anderson EC, Arnold JR. 1949. Age determination by radiocarbon content: world-wide assay of natural radiocarbon. Science 109(2827):227-8.

Long A. 1998. Attempt to affect the apparent ${ }^{14} \mathrm{C}$ age of cotton by scorching in a $\mathrm{CO}_{2}$ environment. Radiocarbon 40(1):57-8.

MacNeish RS. 1999. A Paleolithic-Neolithic sequence from South China Jangxi Province, PRC. In: Omoto $\mathrm{K}$, editor. Interdisciplinary Perspectives on the Origins of the Japanese. Kyoto: International Research Center for Japanese Studies. p 233-55.

Madsen DB, Li J, Brantingham PJ, Gao X, Elston RG, Bettinger RL. 2001. Dating Shuidonggou and the Upper Palaeolithic blade industry in North China. Antiquity 75(290):706-16.

Mamonova NN, Sulerzhitsky LD. 1989. An attempt to date some Holocene burials in the Baikal region according to ${ }^{14} \mathrm{C}$. Sovetskaya Arkheologiya 32(1):19-32. In Russian with English abstract.

Marlowe G. 1980. W F Libby and the archaeologists, 1946-1948. Radiocarbon 22(3):1005-14.

McBurney CBM. 1952. Radiocarbon dating results from the Old World. Antiquity 26(101):35-40.

McGrath RJ, Boyd WE. 2001. The chronology of the Iron Age 'moats' of northeast Thailand. Antiquity 75(288):349-60.

Meacham W. 2007. The amazing Dr Kouznetsov. Antiquity 81(313):779-83.

Mellaart J. 1979. Egyptian and Near Eastern chronology: a dilemma? Antiquity 53(207):6-19.

Mellars P. 2006a. Archaeology and the dispersal of modern humans in Europe: deconstructing the "Aurignacian." Evolutionary Anthropology 15(5):167-82.

Mellars P. 2006b. A new radiocarbon revolution and the dispersal of modern humans in Eurasia. Nature 439(7079):931-5.

Merill RS. 1948. A progress report on the dating of ar- chaeological sites by means of radioactive elements. American Antiquity 13:281-6.

Michael HN. 1984. Absolute chronologies of Late Pleistocene and Early Holocene cultures of northeastern Asia. Arctic Anthropology 21(2):1-68.

Mihara S, Miyamoto K, Nakamura T, Koike H. 2004. ${ }^{14} \mathrm{C}$ age determination for human bones during the Yayoi period-the calibration ambiguity around $2400 \mathrm{BP}$ and the marine reservoir effect. Nuclear Instruments and Methods in Physics Research B 223-224:700-4.

Mitchell PJ. 2002. The Archaeology of Southern Africa. Cambridge: Cambridge University Press. 515 p.

Mochanov YA, Fedoseeva SA. 1985. Main periods in the ancient history of Northeast Asia. In: Kontrimavichus VL, editor. Beringia in the Cenozoic Era. Rotterdam: A.A. Balkema. p 669-93.

Morlan RE. 1967. Chronometric dating in Japan. Arctic Anthropology 4(2):180-211.

Movius Jr HL. 1960. Radiocarbon dates and Upper Palaeolithic archaeology in Central and Western Europe. Current Anthropology 1:355-91.

Nagamoto T, Kajiwara H, Fujimura S, Kamada T, Yokoyama Y. 1999. Luminescence dating of tephra from Paleolithic sites in Japan (from $10 \mathrm{ka}$ to $500 \mathrm{ka}$ ). Radiation Protection Dosimetry 84(1):489-94.

Nakamura T, Taniguchi Y, Tsuji S, Oda H. 2001. Radiocarbon dating of charred residues on the earliest pottery in Japan. Radiocarbon 43(2B):1129-38.

Nelson SM. 1993. The Archaeology of Korea. Cambridge: Cambridge University Press. 307 p.

Nesterov SP, Sakamoto M, Imamura M, Kuzmin YV. 2006. The Late-Glacial Neolithic complex of the Gromatukha site, Russian Far East: new results and interpretations. Current Research in the Pleistocene 23: 46-9.

Nishimura M, Nguyen KD. 2002. Excavation of An Son: a Neolithic mound site in the middle reach of the Vam Co Dong River, southern Vietnam. Bulletin of the Indo-Pacific Prehistory Association 22:101-9.

Nguyen QM. 2005. Radiocarbon dating of the Dong Dau period. Bulletin of the Indo-Pacific Prehistory Association 25:113-5.

Ono A, Oda S, Matsu'ura S. 1999. Palaeolithic cultures and Pleistocene hominids in the Japanese Islands: an overview. Daiyonki Kenkyu 38(3):177-83.

Ono A, Sato H, Tsutsumi T, Kudo Y. 2002. Radiocarbon dates and archaeology of the Late Pleistocene in the Japanese Islands. Radiocarbon 44(2):477-94.

Otte M, Bayón IL, Noiret P, Bar-Yosef O, Yalçînkaya I, Kartal M, Leótard J-M, Pettitt P. 2003. Sedimentary deposition rates and carbon-14: the Epi-Paleolithic sequence of Öküzini Cave (southwest Turkey). Journal of Archaeological Science 30(3):325-41.

Ovchinnikov IV, Götherström A, Romanova GP, Kharitonov VM, Lidén K, Goodwin W. 2000. Molecular analysis of Neanderthal DNA from the northern Caucasus. Nature 404(6777):490-3. 
Panyushkina I, Mills BJ, Usmanova ER, Cheng L. 2008. Calendar age of Lisakovsky timbers attributed to Andronovo community of Bronze Age in Eurasia. Radiocarbon 50(3):459-69.

Pavlov P, Roebroeks W, Svendsen JI. 2004. The Pleistocene colonization of northeastern Europe: a report on recent research. Journal of Human Evolution 47(12):3-17.

Pearson R. 2005. The social context of early pottery in the Lingnan region of south China. Antiquity 79(306): 819-28.

Penny D, Hua Q, Pottier C, Fletcher R, Barbetti M. 2007. The use of AMS ${ }^{14} \mathrm{C}$ dating to explore issues of occupation and demise at the medieval city of Angkor, Cambodia. Nuclear Instruments and Methods in Physics Research B 259(1):388-94.

Pettitt P. 2008. Art and the Middle-to-Upper Paleolithic transition in Europe: comments on the archaeological arguments for an early Upper Paleolithic antiquity of the Grotte Chauvet art. Journal of Human Evolution 55(5):908-17.

Pettitt PB, Bader NO. 2000. Direct AMS radiocarbon dates for the Sungir mid Upper Palaeolithic burials. Antiquity 74(284):269-70.

Pettitt P, Pike A. 2007. Dating European Palaeolithic cave art: progress, prospects, problems. Journal of Archaeological Method and Theory 14(1):27-47.

Pettitt PB, Bronk Ramsey C, Hedges REM, Hodgins GWL. 2000. AMS radiocarbon dating at Oxford and its contribution to issues of the extinction of Neanderthals and the spread of Homo sapiens sapiens across Eurasia. Nuclear Instruments and Methods in Physics Research B 172(1-4):751-5.

Pinhasi R, Foley RA, Lahr M. 2000. Spatial and temporal patterns in the Mesolithic-Neolithic archaeological record of Europe. In: Renfrew C, Boyle K, editors. Archaeogenetics: DNA and Population Prehistory of Europe. Cambridge: MacDonald Institute for Archaeological Research. p 45-56.

Pitulko VV. 2004. The Holocene Stone Age in Northeast Asia. In: Nikolsky PA, Pitulko VV, editors. Estestvennaya Istoriya Rossiiskoi Vostochnio Arktiki v Pleistotsene i Golotsene. Moscow: GEOS Publishing. p 99151. In Russian with English abstract.

Pitulko VV, Pavlova EY, Kuz'mina SA, Nikolsky PA, Basilyan AE, Tumskoy VE, Anisimov MA. 2007. Natural-climatic changes in the Yana-Indigirka lowland during the terminal Karginian time and habitat of Late Paleolithic man in northern part of East Siberia. Doklady Earth Sciences 417(8):1256-60.

Potekhina I, Telegin D. 1995. On the dating of the Ukrainian Mesolithic-Neolithic transition. Current Anthropology 36(5):823-6.

Protsch R, Berger R. 1973. Earliest radiocarbon dates for domesticated animals. Science 179(4070):235-9.

Quitta H. 1967. The $\mathrm{C}_{14}$ chronology of the Central and SE European Neolithic. Antiquity 41(164):263-70.

Ranov VA, Laukhin SA, van der Plicht J. 2002. The first series of radiocarbon dates from the Mousterian sites in Tajikistan. Rossiiskaya Arkheologiya 46(2):5-16. In Russian with English abstract.

Reimer PJ, editor. 2004. IntCal04: Calibration Issue. Radiocarbon 46(3):1029-304.

Renfrew C. 1973. Before Civilization: The Radiocarbon Revolution and Prehistoric Europe. New York: A.A. Knopf. 292 p.

Renfrew C. 2007. Prehistory: The Making of the Human Mind. London: Weidenfeld \& Nicolson. 254 p.

Renfrew C, Bahn P. 2004. Archaeology: Theories, Methods, and Practice. 4th edition. London: Thames \& Hudson. $656 \mathrm{p}$.

Richards MP, Pettitt PB, Stiner MC, Trinkaus E. 2001. Stable isotope evidence for increasing dietary breadth in the European mid-Upper Paleolithic. Proceedings of the National Academy of Sciences of the USA 98(11):6528-32.

Robertshaw P. 1992. Radiocarbon dating and the prehistory of sub-Saharan Africa. In: Taylor RE, Long A, Kra RS, editors. Radiocarbon After Four Decades: An Interdisciplinary Perspective. New York: SpringerVerlag; Tucson: Radiocarbon. p 335-51.

Russell T, Steele J. 2004. Visualising the Neolithic transition in Europe. In: Higham T, Bronk Ramsey C, Owen C, editors. Radiocarbon and Archaeology. Oxford: Oxford University School of Archaeology. p 43-52.

Sankalia HD. 1973. Radiocarbon dates in India, their consistency and cultural implication. In: Agrawal DP, Ghosh A, editors. Radiocarbon and Indian Archaeology. Bombay: Tata Institute of Fundamental Research. p 211-21.

Sato T, Khenzykhenova F, Yoshida K, Kunikita D, Suzuki K, Lipnina E, Medvedev G, Kato H. 2008. Vertebrate fossils excavated from the Bol'shoj Naryn site, East Siberia. Quaternary International 179(1):101-7.

Sayavongkhamdy T, Bellwood P. 2000. Recent archaeological research in Laos. Bulletin of the Indo-Pacific Prehistory Association 19:101-10.

Schmitz RW, Serre D, Bonani G, Feine S, Hillgruber F, Krainitzki H, Pääbo S, Smith FH. 2002. The Neandertal type site revisited: interdisciplinary investigations of skeletal remains from the Neander Valley, Germany. Proceedings of the National Academy of Sciences of the USA 99(2):13,342-7.

Schulting RJ. 2000. New AMS dates from the Lambourn long barrow and the question of the earliest Neolithic in southern England: repacking the Neolithic package? Oxford Journal of Archaeology 19(1):25-35.

Schulting RJ, Trinkaus E, Higham T, Hedges R, Richards M, Cardy B. 2005. A mid-Upper Palaeolithic human humerus from Eel Point, South Wales, UK. Journal of Human Evolution 48(5):493-505.

Sealy JC, Yates R. 1994. The chronology of the introduction of pastoralism to the Cape, South Africa. Antiquity 68(258):58-67.

Séfériadès ML. 2004. An aspect of Neolithisation in Mongolia: the Mesolithic-Neolithic site of Tamsag- 
bulag (Dornod District). Documenta Praehistorica 31:139-49.

Sementsov AA, Zaitseva GI, Görsdorf J, Nagler A, Parzinger $\mathrm{H}$, Bokovenko NA, Chugunov KV, Lebedeva LM. 1998. Chronology of the burial finds from Scythian monuments in southern Siberia and Central Asia. Radiocarbon 40(2):713-20.

Serizawa C. 1967. The Stone Age of Japan and its radiocarbon dates. Daiyonki Kenkyu 6:239-42. In Japanese with English abstract.

Serizawa C. 1976. The Stone Age of Japan. Asian Perspectives 19(1):1-14.

Shang H, Tong H, Zhang S, Chen F, Trinkaus E. 2007. An early modern human from Tianyan Cave, Zhoukoudian, China. Proceedings of the National Academy of Sciences of the USA 104(16):6573-8.

Sharon I, Gilboa A, Jull AJT, Boaretto E. 2007. Report on the first stage of the Iron Age Dating Project in Israel: supporting the Low Chronology. Radiocarbon 49(1): $1-46$.

Shelach G. 2006. Economic adaptation, community structure, and sharing strategies of households at early sedentary communities in northeast China. Journal of Anthropological Archaeology 25(3):318-45.

Shennan S, Edinborough K. 2007. Prehistoric population history: from the Late Glacial to the Late Neolithic in Central and Northern Europe. Journal of Archaeological Science 34(8):1339-45.

Shutler Jr R. 1967. Radiocarbon dating and man in Southeast Asia, Australia, and the Pacific. In: Solheim II WG, editor. Archaeology at the Eleventh Pacific Science Congress. Honolulu: University of Hawaii. p 7987.

Shutler Jr R. 1977. Tom Harrisson's contribution through radiocarbon dating to the understanding of the prehistory of Southeast Asia. Asian Perspectives 20(1):812.

Sinitsyn AA, Hoffecker JF. 2006. Radiocarbon dating and chronology of the early Upper Paleolithic at Kostenki. Quaternary International 152-153:164-74.

Smith C, Bonsall C. 1990. AMS radiocarbon dating of British late Upper Palaeolithic and Mesolithic artefacts: preliminary results. In: Mook WG, Waterbolk HT, editors. Proceedings of the Second International Symposium " ${ }^{4} C$ and Archaeology" (PACT No. 29). Strasbourg: Council of Europe. p 259-68.

Smith FH, Trinkaus E, Pettitt PB, Karavanić I, Paunović M. 1999. Direct radiocarbon dates for Vindija $G_{1}$ and Velika Pećina Late Pleistocene hominid remains. Proceedings of the National Academy of Sciences of the USA 96():12,281-6.

Smith HS. 1964. Egypt and $\mathrm{C}_{14}$ dating. Antiquity 38(149):32-7.

Smith PEL. 1965. Palaeolithic radiocarbon dates from southwestern Europe and the Mediterranean basin. In: Chatters RM, Olson EA, editors. Proceedings of the Sixth International Conference "Radiocarbon and
Tritium Dating." Springfield, Virginia, USA: Clearinghouse for Federal Scientific and Technical Information. p 199-209.

Soficaru A, Doboş A, Trinkaus E. 2006. Early modern humans from the Peştera Muierii, Baia de Fier, Romania. Proceedings of the National Academy of Sciences of the USA 103(46):17,196-201.

Solheim II WG. 1968. Early Bronze in northeastern Thailand. Current Anthropology 9(1):59-62.

Spriggs M. 2003. Chronology of the Neolithic transition in island Southeast Asia and the Western Pacific: a view from 2003. The Review of Archaeology 24(2): $57-80$.

Srdoč D, Horvatinčić N, Mirnik I, Rendić-Moičević A. 1990. Radiocarbon dating of the Liber Linteus Zagrabiensis, an Etruscan Linen Book. In: Mook WG, Waterbolk HT, editors. Proceedings of the Second International Symposium " ${ }^{14} \mathrm{C}$ and Archaeology" (PACT No. 29). Strasbourg: Council of Europe. p 429-38.

Stäuble H. 1995. Radiocarbon dates of the earliest Neolithic in Central Europe. Radiocarbon 37(2):22737.

Straus LG, González Morales M. 2003. El Mirón cave and the ${ }^{14} \mathrm{C}$ chronology of Cantabrian Spain. Radiocarbon 45(1):41-58.

Street M, Terberger T, Orschiedt J. 2006. A critical review of the German Paleolithic hominin record. Journal of Human Evolution 51(6):551-79.

Stuiver M, van der Merwe NJ. 1968. Radiocarbon chronology of the Iron Age in sub-Saharan Africa. Current Anthropology 9(1):54-8.

Sulerzhitsky LD. 2004. The chronological span of some Late Palaeolithic sites according to the radiocarbon dating of the bones of megafauna. Rossiiskaya Arkheologiya 48(3):103-12. In Russian with English abstract.

Svezhentsev YuS, Popov SG. 1993. Late Paleolithic chronology of the East European Plain. Radiocarbon 35(3):495-501.

Svoboda JA, Novák M. 2004. Eastern Central Europe after the Upper Pleniglacial: changing points of observation. Archäologisches Korrespondenzblatt 34:46377.

Switsur VR, Jacobi RM. 1979. A radiocarbon chronology for the early Postglacial stone industries of England and Wales. In: Berger R, Suess HE, editors. $R a-$ diocarbon Dating. Berkeley: University of California Press. p 41-68.

Takamiya H, Obata H. 2002. Peopling of western Japan, focusing on Kyushu, Shikoku, and Ryukyu archipelago. Radiocarbon 44(2):495-502.

Tang C. 2000. The Upper Paleolithic of North China: the Xiachuan culture. Journal of East Asian Archaeology 2(1-2):37-49.

Tauber H. $1990 .{ }^{14} \mathrm{C}$ dating of Stone Age cultures in Denmark. In: Mook WG, Waterbolk HT, editors. Proceed- 
ings of the Second International Symposium " ${ }^{14} \mathrm{C}$ and Archaeology" (PACT No. 29). Strasbourg: Council of Europe. p 379-94.

Taylor RE. 1987. Radiocarbon Dating: An Archaeological Perspective. Orlando, Florida, USA: Academic Press. $212 \mathrm{p}$.

Taylor RE. 1997. Radiocarbon dating. In: Taylor RE, Aitken MJ, editors. Chronometric Dating in Archaeology. New York: Plenum Press. p 65-96.

Taylor RE. 2000. The introduction of radiocarbon dating. In: Nash SE, editor. It's About Time: A History of Archaeological Dating in North America. Salt Lake City: University of Utah Press. p 84-104.

Taylor RE, Berger R. 1980. The date of 'Noah's Ark'. Antiquity 54(210):34-6.

Timofeev VI, Zaitseva GI. 1999. On the problem of the Neolithisation of eastern Europe and the position of the south Russian area in this process. Mémoires de la Societé Préhistorique Française 26:189-202.

Timofeev VI, Zaitseva GI, Dolukhanov PM, Shukurov AM. 2004. Radiouglerodnaya Khronologiya Neolita Severnoi Evrazii [Radiocarbon Chronology of the Neolithic of Northern Eurasia]. St. Petersburg: Teza Publishing. 157 p. In Russian.

Tolan-Smith C, Bonsall C. 1999. Stone Age studies in the British Isles: the impact of accelerator dating. Mémoires de la Societé Préhistorique Française 26:249-57.

Trinkaus E, Milota Ş, Rodrigo R, Mircea G, Moldovan O. 2003. Early modern human cranial remains from the Peştera cu Oase, Romania. Journal of Human Evolution 45(3):245-53.

Tripathi V. 1990. Early historic archaeology of India and radiocarbon dating. In: Mook WG, Waterbolk HT, editors. Proceedings of the Second International Symposium " ${ }^{14} \mathrm{C}$ and Archaeology" (PACT No. 29). Strasbourg: Council of Europe. p 289-303.

Tsuji S, Nakamura T. 2001. High-precision chronology of the Jomon period: a dating of the Sannai-Maruyama site, Aomori Prefecture, northern Japan. Daiyonki Kenkyu 40:471-84. In Japanese with English abstract.

Tuniz C, Bird JR, Fink D, Herzog GF. 1998. Accelerator Mass Spectrometry: Ultrasensitive Analysis for Global Science. Boca Raton, Florida, USA: CRC Press. $371 \mathrm{p}$.

Uchida E, Cunin O, Shimoda I, Takubo Y, Nakagawa T. 2008. AMS radiocarbon dating of wood samples from the Angkor monuments, Cambodia. Radiocarbon 50(3):437-45.

Ugan A, Byers D. 2007. Geographic and temporal trends in proboscidean and human radiocarbon histories during the Late Pleistocene. Quaternary Science Reviews 26(25-28):3058-80.

Underhill P. 1997. Current issues in Chinese Neolithic archaeology. Journal of World Prehistory 11(2):103-60.

Valladas H, Cachier H, Maurice P, Bernaldo de Quiros F, Clottes J, Cabrera Valdés V, Uzquiano P, Arnold M. 1992. Direct radiocarbon dates for prehistoric paint- ings at the Altamira, El Castillo and Niaux caves. $\mathrm{Na}$ ture 357(6373):68-70.

Valladas H, Tisnérat-Laborde N, Cachier H, Arnold M, Bernaldo de Quirós F, Cabrera-Valdés V, Clottes J, Courtin J, Fortea-Pérez JJ, Gonzáles-Sainz C, MoureRomanillo A. 2001. Radiocarbon AMS dates for Paleolithic cave paintings. Radiocarbon 43(2B):977-86.

van Andel TH, Davies W, editors. 2003. Neanderthals and Modern Humans in the European Landscape during the Last Glaciation. Cambridge: MacDonald Institute for Archaeological Research. 265 p.

Van Strydonck M, Nelson DE, Crombé P, Bronk Ramsey C, Scott EM, van der Plicht J, Hedges REM. 1999. What's in a ${ }^{14} \mathrm{C}$ date. Mémoires de la Societé Préhistorique Française 26:433-40.

Van Strydonck M, De Moor A, Bénazeth D. 2004. ${ }^{14} \mathrm{C}$ dating compared to art historical dating of Roman and Coptic textiles from Egypt. Radiocarbon 46(1):23144.

Vasil'ev SA, Kuzmin YV, Orlova LA, Dementiev VN. 2002. Radiocarbon-based chronology of the Paleolithic in Siberia and its relevance to the peopling of the New World. Radiocarbon 44(2):503-30.

Vermeersch PM. 2005. European population changes during marine isotope stages 2 and 3. Quaternary International 137(1):77-85.

Verpoorte A. 2004. Eastern Central Europe during the Pleniglacial. Antiquity 78(300):257-66.

Verpoorte A. 2005. The first modern humans in Europe? A closer look at the dating evidence from the Swabian Jura (Germany). Antiquity 79(304):269-79.

Vetrov VM, Kuzmin YV, Burr GS. 2006. The FinalPleistocene pottery of Siberia: Ust'-Karenga 12 site case study. Current Research in the Pleistocene 23: 49-51.

Vishnyatsky LB. 1999. The Paleolithic of Central Asia. Journal of World Prehistory 13(1):69-122.

Vogel JC, Beaumont PB. 1972. Revised radiocarbon chronology for the Stone Age in South Africa. Nature 237(5349):50-1.

Watanabe N. 1966. Radiocarbon dates of the Jomon and Yayoi periods in Japan. Daiyonki Kenkyu 5:157-66. In Japanese with English abstract.

Waterbolk HT. 1968. Food production in prehistoric Europe. Science 162(3858):1093-102.

Waterbolk HT. 1971. Working with radiocarbon dates. Proceedings of the Prehistoric Society 37(2):15-33.

Waterbolk HT. 1983a. Thirty years of radiocarbon dating; the retrospective view of a Groningen archaeologist. In: Mook WG, Waterbolk HT, editors. Proceedings of the First International Symposium $"{ }^{14} \mathrm{C}$ and Archaeology" (PACT No. 8). Strasbourg: Council of Europe. p 17-27.

Waterbolk HT. 1983b. The integration of radiocarbon dating in archaeology. Radiocarbon 25(2):639-44.

Waterbolk HT. 1994. Radiocarbon dating Levantine prehistory. In: Bar-Yosef O, Kra RS, editors. Late Qua- 
ternary Chronology and Paleoclimates of the Eastern Mediterranean. Tucson, Arizona, USA: Radiocarbon. p 351-71.

Waterbolk HT. 1999. Archaeology and radiocarbon dating 1948-1998: a golden alliance. Mémoires de la Societé Préhistorique Française 26:11-7.

Watts WA. 1960. C-14 dating and the Neolithic in Ireland. Antiquity 34(134):111-6.

Weber A. 1995. The Neolithic and Early Bronze Age of the Lake Baikal region: a review of recent research. Journal of World Prehistory 9(1):99-165.

Weber AW, Beukens RP, Bazaliiski VI, Goriunova OI, Savel'ev NA. 2006. Radiocarbon dates from Neolithic and Bronze Age hunter-gatherer cemeteries in the CisBaikal region of Siberia. Radiocarbon 48(1):127-66.

Wendorf F. 1992. The impact of radiocarbon dating on North African archaeology. In: Taylor RE, Long A, Kra RS, editors. Radiocarbon After Four Decades: An Interdisciplinary Perspective. New York: SpringerVerlag; Tucson: Radiocarbon. p 310-23.

Wendorf F, Schild R, Close AE, Donahue DJ, Jull AJT, Zabel TH, Wieckowska H, Kobusiewicz M, Issawi B, El Hadidi N. 1984. New radiocarbon dates on the cereals from Wadi Kubbaniya. Science 225(4662):645-6.

Weninger B, Jöris O. 2004. Glacial radiocarbon age calibration: the CALPAL program. In: Higham T, Bronk Ramsey C, Owen C, editors. Radiocarbon and Archaeology. Oxford: Oxford University School of Archaeology. p 9-15.

White JC. 1997. A brief note on new dates from the Ban Chiang cultural tradition. Bulletin of the Indo-Pacific Prehistory Association 16:103-6.

White JC. 2004. Comment on dates from a resin-coated sherd from Spirit Cave, Thailand. Antiquity 78(299): 184-6.

Wild EM, Teschler-Nicola M, Kutschera W, Steier P, Trinkaus E, Wanek W. 2005. Direct dating of early Upper Palaeolithic human remains from Mladeč. $\mathrm{Na}$ ture 435(7040):332-5.

Wu X, Zhao C. 2003. Chronology of the transition from Palaeolithic to Neolithic in China. The Review of Archaeology 24(2):15-20.

Yi S, Lee J-J, Kim S, Yoo Y, Kim D. 2008. New data on the Hoabinhian: investigations at Hang Cho Cave, northern Vietnam. Bulletin of the Indo-Pacific Prehistory Association 28:73-9.

Yoneda M, Hirota M, Uchida M, Tanaka A, Shibata Y, Morita M, Akazawa T. 2002. Radiocarbon and stable isotope analyses of the earliest Jomon skeletons from the Tochibara rockshelter, Nagano, Japan. Radiocar- bon 44(2):549-57.

Youn M, Kim IC, Park JH, Kim JC, Ahn J. 2004. Radiocarbon dating of the pottery artefacts from the Sejuk Neolithic site. In: Higham T, Bronk Ramsey C, Owen C, editors. Radiocarbon and Archaeology. Oxford: Oxford University School of Archaeology. p 99-104.

Youn M, Kim JC, Kim HK, Tumen D, Navaan D, Erdene M. 2007. Dating the Tavan Tolgoi site, Mongolia: burials of the nobility from Genghis Khan's era. $R a$ diocarbon 49(2):685-91

Yuan S, Zhou G, Guo Z. Zhang Z, Gao S, Li K, Wang J, Liu K, Li B, Lu X. 1995. ${ }^{14} \mathrm{C}$ AMS dating the transition from the Paleolithic to the Neolithic in South China. Radiocarbon 37(2):245-9.

Zaitseva GI, Popov SG, Krylov AP, Knorozov YV, Spevakovskiy AB. 1993. Radiocarbon chronology of archaeological sites of the Kurile Islands. Radiocarbon 35(3):507-10.

Zaitseva GI, Vasiliev SS, Marsadolov LS, van der Plicht J, Sementsov AA, Dergachev VA, Lebedeva LM. 1998. A tree-ring and ${ }^{14} \mathrm{C}$ chronology of the key Sayan-Altai monuments. Radiocarbon 40(1):571-80.

Zaitseva GI, Chugunov KV, Alekseev AYu, Dergachev VA, Vasiliev SS, Sementsov AA, Cook G, Scott EM, van der Plicht J, Parzinger H, Nagler A, Jungner H, Sonninen E, Bourova ND. 2007. Chronology of key barrows belonging to different stages of the Scythian period in Tuva (Arzhan-1 and Arzhan-2 barrows). $R a$ diocarbon 49(2):645-58.

Zapata L, Peña-Chocarro L, Pérez-Jordá G, Stika H-P. 2004. Early Neolithic agriculture in the Iberian Peninsula. Journal of World Prehistory 18(4):283-325.

Zilhão J. 2001. Radiocarbon evidence for maritime pioneer colonization at the origins of farming in west Mediterranean Europe. Proceedings of the National Academy of Sciences of the USA 98(24):14,180-5.

Zilhão J. 2007. The emergence of ornaments and art: an archaeological perspective on the origins of "behavioral modernity." Journal of Archaeological Research 15:1-54.

Zilhão J, d'Errico F. 1999. The chronology and taphonomy of the earliest Aurignacian and its implications for the understanding of Neanderthal extinction. Journal of World Prehistory 13(1):1-68.

Zoppi U, Barbetti M, Fletcher R, Hua Q, Chhem RK, Pottier C, Watanasak M. 2004. The contribution of ${ }^{14} \mathrm{C}$ AMS dating to the Greater Angkor archaeological project. Nuclear Instruments and Methods in Physics Research B 223-224:681-5. 